\title{
THE SIZE AND
}

COMPOSITION OF

\section{GOVERNMENT DEBT}

IN THE EURO AREA

by Dagmar Hartwig Lojsch,

Marta Rodriguez-Vives

and Michal Slavík 


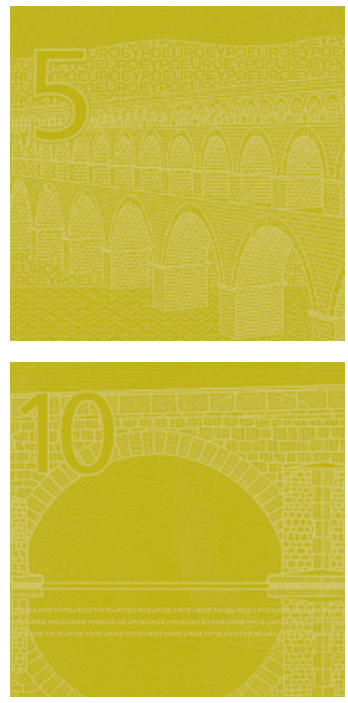

\section{OCCASIONAL PAPER SERIES} NO I32 / OCTOBER 20 II

THE SIZE AND COMPOSITION OF GOVERNMENT DEBT IN THE EURO AREA

by Dagmar Hartwig Lojsch, Marta Rodríguez-Vives and Michal Slavik'

NOTE: This Occasional Paper should not be reported as representing the views of the European Central Bank (ECB).

The views expressed are those of the authors and do not necessarily reflect those of the $E C B$.

This paper can be downloaded without charge from http://www.ecb.europa.eu or from the Social Science Research Network electronic library at http://ssrn.com/abstract_id $=1932062$. 
(C) European Central Bank, 2011

\section{Address}

Kaiserstrasse 29

60311 Frankfurt am Main, Germany

\section{Postal address}

Postfach 160319

60066 Frankfurt am Main, Germany

Telephone

+496913440

Internet

http://www.ecb.europa.eu

Fax

+496913446000

All rights reserved.

Any reproduction, publication and reprint in the form of a different publication, whether printed or produced electronically, in whole or in part, is permitted only with the explicit written authorisation of the ECB or the authors.

Information on all of the papers published in the ECB Occasional Paper Series can be found on the ECB's website, http://www.ecb.europa.eu/pub/ scientific/ops/date/html/index.en.html. Unless otherwise indicated, hard copies can be obtained or subscribed to free of charge, stock permitting, by contacting info@ecb.europa.eu

Unless otherwise indicated, the cut-off date for the statistics included in this Occasional Paper was May 2011.

ISSN 1607-1484 (print)

ISSN 1725-6534 (online) 


\section{CONTENTS}

ABSTRACT

NON-TECHNICAL SUMMARY

I INTRODUCTION

2 A CONCEPTUAL FRAMEWORK FOR THE MEASUREMENT OF GOVERNMENT DEBT

3 THE SIZE OF GOVERNMENT DEBT

3.1 Government liabilities and government debt

3.2 Government debt in the euro area countries

3.3 Government assets and net government debt

3.4 Government assets and net debt in the euro area countries

4 OFF-BALANCE-SHEET ASSETS AND LIABILITIES

4.1 Contingent liabilities

4.2 Implicit assets and liabilities

5 THE COMPOSITION

OF GOVERNMENT DEBT

6 CONCLUSIONS

REFERENCES

ANNEXES

1 Government EDP debt in euro area countries over the period 1999 to 2012

2 Financial assistance provided to euro area countries via bilateral loans and the EFSF

LIST OF BOXES:

1 Historical government debt in the selected euro area countries

2 Government debt in the US and Japan 


\section{ABSTRACT}

This paper explains the various concepts of government debt in the euro area with particular emphasis on its size and composition. In terms of size, the paper focuses on different definitions that are in use, in particular the concept of gross general government debt used in the surveillance of the euro area countries, the total liabilities from the government balance sheet approach, and the net debt concept which subtracts government financial assets from the liability side. In addition, it discusses "hidden debt" in the form of implicit and contingent liabilities. In terms of composition, the paper provides information about euro area government debt broken down by maturity, holder or the currency of issue. All these indicators illustrate a sharp increase in government debt in most euro area countries as a result of the crisis. This in turn has several policy implications: (i) the growing government debt ratios need to be stabilised and put on a downward path which improves market confidence; (ii) fiscal surveillance needs to put more emphasis on government debt indicators than in the past; (iii) government financial assets could play a role when analysing solvency issues; (iv) implicit and other off-balance-sheet government liabilities need to be carefully monitored and reported; (v) the gross debt concept should remain the key basis for fiscal surveillance in the EU and for the Excessive Deficit Procedure in particular; (vi) beyond the size of government debt its composition is also a key factor behind public finance vulnerabilities.

JEL code: E10, E62, G15, H30, H6.

Keywords: Fiscal policies, government debt, sustainability, stability and growth pact. 


\section{NON-TECHNICAL SUMMARY}

Government debt is one of the most frequently used concepts in the ongoing economic debate: for example, countries are compared and ranked according to the sustainability of their public finances, which takes existing government debt as the starting point; investors are closely monitoring the credit default risks on sovereign debt; public debt management offices are actively trying to reduce rollover risks related to government debt; and economic and fiscal policies are designed to influence the future trajectory of government debt. As a result, government debt, as an indicator of government borrowing activity, is (again) receiving more prominence in both national and supranational fiscal frameworks.

There are several policy implications arising from current government debt trajectories which have been substantially affected by the crisis: (i) growing government debt ratios need to be stabilised and put on a sustainable path which ensures market confidence; (ii) fiscal surveillance needs to put more emphasis on government debt indicators than in the past, (iii) government financial assets can be relevant when analysing solvency issues; (iv) 'hidden debt' in the form of implicit and other off-balance-sheet government liabilities also needs to be carefully monitored and reported; (v) beyond the size of government debt, its composition is also a key factor in determining public finance vulnerabilities.

Despite the fact that the term government debt is used so frequently, it spans different concepts with different nuances. There are several meaningful ways in which to define and measure government debt. Moreover, the role and the size of governments have evolved over time, and the statistical concepts and available data on government debt have continuously adapted to the new challenges. The aim of this paper is to shed some light on the differences between various concepts of government debt frequently used in the European Union and put them on a quantitative scale both from the temporal and cross-country perspectives.
The paper also seeks to present details of the composition of government debt in terms of financial instruments, currency and maturity.

In the first part of this paper, the size of government debt is analysed using different concepts for the measurement of government debt. The first sub-section focuses on gross government debt (based on the EDP and ESA debt concepts). It also provides an example of how gross government debt has evolved historically in the five biggest euro area countries, showing that substantial debt reductions were feasible in the past. The next sub-section focuses on the size of government financial assets and provides an estimate of its development in the euro area. The aggregated data show that total financial assets were approximately $35 \%$ of GDP in 2010. However, the size (and composition) of financial assets differs remarkably between the euro area countries; as a result, the relative buffer that asset positions bring to the growing gross debt burden is somewhat heterogeneous. Knowledge of financial assets allows us to construct the net debt-to-GDP ratio for the euro area, which was around 57\% of GDP in 2010 . International comparisons show that the US, and especially Japan, are no better off, with an equivalent net debt of around $58 \%$ of GDP for the US, and some $110 \%$ of GDP for Japan. The third sub-section addresses the issue of off-balance-sheet items which are not captured in the estimates of gross or net government debt. The financial crisis led governments to issue both explicit and contingent liabilities in order to stabilise the financial sector in 2008-10, although their magnitude also varies across the euro area countries. On average, explicit liabilities amounted to around $5.5 \%$ of GDP and are already included in the gross figures for general government debt, while contingent liabilities (i.e. recorded off-balance sheet) amounted to some $6.5 \%$ of GDP.

In part two, the composition of government debt is analysed with respect to the type of financial instrument, the level of government which issued the instrument, the currency composition, and residual and average maturity. Data for 2010 
show that the three main types of financial instrument used for financing gross government debt in the euro area were long-term government bonds $(70 \%$ of the total), loans $(18 \%)$ and short-term government bills (9\%). The majority of debt was issued by central governments ( $83 \%$ of the total), while state and local governments respectively issued only around $10 \%$ and $7 \%$ of total overall government debt in the euro area, and social security funds less than $1 \%$. Another finding is that virtually the entire euro area government debt is denominated in euro ( $99 \%$ of the total). Moreover, $26 \%$ of general government debt has residual maturity at under one year, around $34 \%$ of debt reaches maturity at between one and five years, and roughly $40 \%$ of debt reaches maturity at over five years. The average residual maturity of euro area government debt is around 6.6 years. However, the average residual maturity varies across the countries: for example, it is approximately five years in Finland and Luxembourg and some eight years in Austria and Italy. Non-resident creditors (including those in another euro area country) held about $52 \%$ of total government debt in 2010 .

Overall, average fiscal vulnerabilities in the euro area have increased. They stem from both the higher levels of explicit and off-balance-sheet debt and from the composition of debt reliant on short-term financing and foreign holders. 
I

\section{INTRODUCTION}

The 2008-10 financial, economic and sovereign crises have left in their wake a substantial fiscal burden for governments in the euro area countries. Government debt-to-GDP ratios have increased sharply, also as a direct consequence of economic contractions and counter-cyclical fiscal policies. The increased level of government borrowing throughout the developed world is likely to raise governments' financing costs, with a possible adverse impact on private financing conditions and a crowding-out of private investment, thus lowering potential economic growth. Moreover, the sharp increases in government debt ratios have adversely affected the markets' confidence in government liquidity and solvency in several countries.

The euro area's government gross-debt-to-GDP ratio $^{1}$ is expected to increase by roughly 22.3 percentage points (p.p.) of GDP over the period $2007-12$, from $66.2 \%$ to $88.5 \%$ of GDP, which equates to one-third more debt compared to the pre-crisis level (2007). The level of government debt by 2012 is expected to increase by an amount of almost EUR 2700 billion from a stock of around EUR 6000 billion in 2007, i.e. a very tough legacy to manage. This debt accumulation is mainly a consequence of the automatic fiscal stabilisers, expansionary counter-cyclical fiscal policies and government support to the financial sector. ${ }^{2}$ While substantial in size, public indebtedness varies between the euro area countries. First, major divergences exist in terms of the government deficit as a major contributor to the increase in nominal debt levels. The deficit-to-GDP ratios for 2010 differ remarkably, ranging from two-digit deficits in Ireland and Greece to deficits lower than the Maastricht Treaty's " $3 \%$ of GDP" reference value in Luxembourg and Finland or even a small surplus in Estonia. Second, precrisis government debt stocks differed - in many instances governments were already highly indebted in 2007 , i.e. above the " $60 \%$ of GDP" reference value laid down in the Maastricht Treaty. Third, and subsequent to the recent high deficit levels, the scale of the recent growth rates in government debt varies across the euro area countries: Belgium, Estonia, Cyprus, Malta and Austria on the one hand are experiencing relatively minor increases in their government debt-to-GDP ratios, but increases over the period 2007-12 are expected to be huge in Ireland (roughly 93 p.p. of GDP), Greece (about 61 p.p. of GDP), Portugal (around 39 p.p. of GDP), and Spain (around 35 p.p. of GDP). Fourth, there is a precedent in terms of mounting government debt ratios, as a number of countries witnessed major increases in their government debt ratios as a consequence of the Second World War. Government debt ratios also increased in association with the oil crises in the 1970s and the generalisation of social welfare policies in Europe since the 1980s. The problem this time is that government debt which accumulated during the last three decades was not fully offset in many cases during the "good times". Moreover, government indebtedness will soon become even more difficult to manage owing to Europe's ageing population (rising government expenditure expected on pensions and health care) and lower overall saving ratios.

This highlights the need to give a more prominent role to the government debt criterion in budgetary surveillance within the context of the Stability and Growth Pact (SGP) and to take account of a wider and deeper spectrum of debt measurements for analysing the sustainability of public finances in the euro area countries. ${ }^{3}$ This is of policy relevance because unsustainable debt developments adversely affect the functioning of Economic and Monetary Union (EMU). Developments as regards government debt ratios in some countries before the crisis were substantially affected by increases in debt that were not recorded in the fiscal deficit

1 Government debt refers to the EDP debt concept, unless otherwise indicated (see Section 3.1 for debt definitions). Forecasts are taken from the European Commission's European Economic Forecast - Spring 2011.

2 For the euro area, see van Riet (ed.) (2010). For a comparison of the euro area with the G7 countries, see, for example, Rother et al. (2010, p. 11).

3 See ECB (2011a) and ECB (2011b). 
under the existing accounting framework and related surveillance procedures. Future fiscal surveillance must give more prominence to government debt indicators compared to past practices. Moreover, the implementation of credible plans to reverse the rise in government debt must safeguard market confidence in the fiscal sustainability of government debt within the euro area countries. All governments must convince the markets about their boundless determination to keep the government debt ratio on a sustainable path, e.g. by implementing a consolidation strategy.

The aim of this paper is to analyse government debt in the euro area both in terms of size and composition, with reference to individual euro area countries to illustrate the uses and implications of detailed government debt assessments. The paper is structured as follows: after this introduction, Section 2 gives an overview of the concepts used for the measurement of government debt; Section 3 shows the possible extended measurements of government debt, with a particular focus on the implications of the size of government debt in the assessment of fiscal risks; Section 4 deals with the 'hidden debt' implied by offbalance-sheet government liabilities; Section 5 focuses on the composition of debt, including the implications for debt portfolio management strategies; finally, Section 6 outlines a set of conclusions. 


\section{A CONCEPTUAL FRAMEWORK FOR THE MEASUREMENT OF GOVERNMENT DEBT}

In theory, a government accumulates debt as the result of previous fiscal deficits when government expenditure exceeded government revenue. In practice, the relationship between debt and deficits is more complicated and other factors come into play, for example additional borrowing requirements from the net acquisition of financial assets $^{4}$, the market-to-face-value adjustment ${ }^{5}$, the change in the value of debt denominated in foreign currency ${ }^{6}$, and remaining statistical adjustments ${ }^{7}$ compiled under the deficit-debt adjustment (DDA). ${ }^{8}$ Government debt can be expressed in terms of level, per capita, or as a ratio of GDP. In the latter case, the ratio $\left(D_{t}\right)$ provides information about the size of government debt in relation to the size of an economy, which is a key factor in determining the tax-earning capacity and thus the ultimate scope for debt servicing. The relationship between debt and deficit (as a ratio of GDP) can be expressed as:

$\frac{D_{\mathrm{t}}-D_{t-1}}{G D P_{\mathrm{t}}}=\frac{E X P_{t}-R E V_{t}}{G D P_{\mathrm{t}}}+\frac{D D A_{t}}{G D P_{\mathrm{t}}}$

where $\mathrm{D}_{t-1}$ is the debt at the end of period $t-1$, which together with the difference between expenditure $E X P_{t}$ and revenue $R E V_{t}$ plus the deficit-debt adjustment $D D A_{t}$ gives the stock of outstanding government debt $\left(\mathrm{D}_{t}\right)$ at the end of period $t$.

High and growing government debt may impact on nominal (and real) interest rate levels. In addition, mounting government debt increases interest expenditure and crowds out other expenditure possibly more favourable to economic growth such as government investment. A 'snowball' effect, where higher debt increases government interest expenditure, which is financed by additional issuance of debt, causes a vicious circle that may be detrimental to the sustainability of the public finances and overall economic conditions.
Empirical evidence suggests that high government debt levels hamper economic growth and discourage capital accumulation (see, for example, Checherita and Rother, 2010). The normal channels in this regard are possible rises in inflation, higher real longterm interest rates, lower private investments, expected rises in distortionary taxation and lower growth-enhancing primary spending. In some cases, an unsustainable growth in debt relative to GDP may trigger an outflow of capital from a country and contribute to a banking or exchange rate crisis (see, for example, Reinhart and Rogoff, 2009).

The importance of analysing the size of government debt is linked to answering questions related to a government's solvency. A government is solvent in the period $t$ if the discounted value of its current and future budget balance surpluses is higher than the sum of the initial stock of debt and the discounted value of future budget deficits. In the European context, gross government debt should not exceed the Treaty reference value of $60 \%$ of GDP, unless it is declining at a satisfactory pace. In theory, a government should always be able to finance its existing and future gross debt liabilities via higher taxation, (financial or non-financial) asset sales (privatization) or reductions in its liabilities (e.g. via legislative reform of the

4 Government financial investment via transactions in deposits held by the Ministry of Finance or other government units at the National Central Banks (NCBs) and other monetary financial institutions (MFIs), the net acquisition of non-government securities by social security funds, and the net acquisition of equity held by government in public corporations increases the borrowing requirement (the amounts that government needs to borrow to finance its activities) and thereby also government debt, while leaving the deficit unchanged.

5 Government debt (and thereby the change in debt) is recorded at nominal (or face) value, whereas financial transactions are recorded at market value including accrued interest.

6 The outstanding amount of debt denominated in foreign currency may vary due to changes on the balance sheet date at current exchange rates, thus producing foreign exchange holding gains and losses.

7 Other deficit-debt adjustments include the time of recording differences, transactions in financial derivatives, statistical discrepancies and other changes in the volume of debt.

8 See ECB (2007)
2 A CONCEPTUAL

FRAMEWORK FOR

THE MEASUREMENT

OF GOVERNMENT

DEBT 
pension system) and thus always be solvent. In practice, this is not always the case, due to political or economic constraints (see, for example, Trabandt and Uhlig, 2010, who find that some European countries are already on the wrong side of the Laffer curve for capital income taxation, meaning they cannot increase capital income taxes further in order to generate additional revenues). In addition, the assessment of solvency is not an easy task due to possible threshold effects and nonlinearities. For example, financial markets may respond smoothly to an increase in the debt ratio, but quickly reassess their willingness to finance additional government debt when the debt ratio reaches certain thresholds (see, for example, Bayoumi et al. (1995) for evidence from the US that credit markets do provide incentives for sovereign borrowers to restrict borrowing and that these incentives appear to be imposed gradually at first, but eventually yield spreads that rise on a steep, non-linear curve). More recently, Schuknecht et al. (2010, p. 16) when analysing USD and DM/EUR denominated government bond spreads before and after the start of the financial crisis, provide evidence that there are nonlinearities in the markets' pricing of sovereign risk with respect to fiscal balance and government debt. In addition, Attinasi et al. (2009) provide evidence that higher expected budget deficits and/or higher government debt ratios relative to Germany contributed to higher government bond yield spreads in the euro area during end-July 2007 to end-March 2009 and that the announcements of bank rescue packages led to a re-assessment on the part of investors of sovereign credit risk, mainly through a transfer of risk from the private financial sector to the government.

From a different angle, the composition of debt has important implications for the government's liquidity position. A government is liquid in the period $t$ if the available finances and the government's liquid assets in a given currency denomination are in line with the maturing liabilities. In particular, the maturity profile of government debt is relevant for the analysis of possible liquidity problems, i.e. refinancing risks in the event of rising outstanding short-term debt (less than one year). This in turn determines the debt portfolio management strategy based on a given cost-risk ratio. When looking at various time horizons, there is a need to assess the shortterm financing risks and also to consider debt composition, exchange rate risks and the degree of liquidity of financial assets in order to assess the room for fiscal policy manoeuvre necessary to achieve a sound medium-term budgetary position. Hence, alongside the level of the debt ratio, analysis of the composition of government debt (debt maturity, residency of holders, currency denomination) is also warranted.

Both the liquidity and the solvency aspects of government debt have implications for the sustainability of public finances and the surrounding intrinsic fiscal risks. Debt sustainability ${ }^{9}$ generally refers to the ability of the government to manage its public finances by servicing its debt obligations while meeting the provision of goods and services for society, both now and in the future. A simple starting point for the assessment of sustainability risks relates to the evolution of the (explicit) government debt-to-GDP ratio, as high and rising debt ratios already hint at potential sustainability problems in the government budget constraint. More exhaustively, sustainability has a liquidity dimension - i.e. whether governments are able to roll over their maturing debt obligations in an orderly manner - and is linked to long-term solvency and the intertemporal budget constraint i.e. current government debt plus the net present value of all future expenditure should be equal to the discounted value of all future revenues. This is known as the government budget constraint, which indicates that the government must run sufficiently large primary surpluses (i.e. the overall balance net of interest payments) in the future in order to cover the cost of servicing its debt, which can be expressed as follows:

$D_{0}-\sum_{t=1}^{\infty} \frac{p b_{t}}{(1+r)^{t}}=0$

9 The issue of sustainability is well covered by extensive literature (see, for example, Giammarioli et al. (2007), the European Commission (2009) and the ECB (2011)). 
where $\mathrm{D}_{0}$ is the debt-to-GDP ratio at time $\mathrm{t}=0$; $\mathrm{pb}_{\mathrm{t}}$ is the primary balance-to-GDP ratio at time $\mathrm{t}$; and $r$ is the differential between the nominal interest rate and the nominal GDP growth rate.

In this respect, Buiter et al. (1985) claim that an explosive debt-deficit spiral is a policy choice rather than a deep structural property of the economy, since there are many alternative debt-stabilising tax-transfer options that can be used as government debt-stabilising instruments. However, more recent studies, for example Davig and Leeper (2010), show that as government debt levels and tax rates rise in the era of fiscal stress, the population's tolerance of taxation declines and the probability of reaching the fiscal limit increases. They understand the fiscal limit as an (economy-specific) point beyond which tax collections can no longer rise and government expenditure cannot be reduced any further.

All of this has implications for the capacity of governments to finance themselves in the markets. Uncertainty about the sustainability of public finances may affect overall financial stability. For example, the government funding frictions related to rollover risk may adversely affect the cost of commercial bank funding, and the illiquidity of certain segments of sovereign debt markets might affect banks' behaviour and reduce the flow of credit into the economy (see ECB (2010b)).

Brixi and Schick (2002) and Giammarioli et al. (2007) break down government liabilities into four categories, i.e. depending on the realisation of a particular event they can be contingent or non-contingent liabilities; additionally, government liabilities can be explicit or implicit, i.e. depending on whether government obligations have a written legal basis or not. Hence, apart from the non-contingent and explicit government debt that is recorded on the government balance sheet, there are potential liabilities that are recorded off-balance sheet, namely contingent (explicit) and non-contingent (implicit) liabilities, that pose additional risks to the sustainability of the public finances. As these two off-balance-sheet items may impact on the government debt recorded in the accounting system, they can be seen as 'hidden debt' (see also Table 1). Theoretically, there is another possible combination - namely, contingentimplicit liabilities - which is not covered in our analysis and relates to hypothetical events for which governments a priori do not have legal obligations, e.g. disaster relief, environmental damage, or financing of the military.

More specifically, contingent liabilities occur when the existence of government obligations (e.g. a law or a written contract) depends on the occurrence of a particular event. A case in point are government guarantees to secure bank liabilities in the event of the debtor (bank) being unable to meet its liabilities as granted during the financial crisis in the euro area. As another example, if a deposit institution were to go bankrupt, the government would ensure that the retail depositors are fully or partly compensated. Often, contingent liabilities are based on the existing law or a written contract between the government and other entity which specifies the conditionality and the amount of the government's future payment.

Implicit liabilities are also off-balance-sheet items but their nature is different as they occur when the existence of government obligations has no legal basis and arise as a consequence of expectations created by past practices or pressures from interest groups. They are less binding (e.g. not explicitly enshrined in law or a contract) for the government, which then has some room for manoeuvre. For example, if an important state-owned company is about to go bankrupt, the government may cover the existing firm's losses in order to allow its continued operation and prevent its liquidation. Another example are the particularly sizeable implicit liabilities in the case of the future accrued pension rights stemming from the unfunded pay-as-you-go (PAYG) public pension pillar (e.g. European Commission 2009). There is no explicit commitment that would guarantee a set income for pensioners in the future (in the defined-contribution schemes), or pension
2 A CONCEPTUAL

FRAMEWORK FOR

THE MEASUREMENT

OF GOVERNMENT

DEBT 
income is dependent (within defined-benefit schemes) on characteristics which will be known only in the future when retirement takes place, such as the total length of working life, salary, factors affecting indexation, etc. Despite the fact that the government's pension liabilities are not explicitly quantified, the contributors expect that a government will honour its commitments and provide an adequate level of pensions for participants. Moreover, implicit liabilities can also include the government's willingness to provide systemic and economic support for important institutions in trouble, or to finance cultural heritage, defence, or costs related to a natural disaster.

In addition, it should be noted that there are also implicit assets that will partially counterbalance the potential burden of governments, such as deferred tax revenues (see, for example, Buiter 1983 and Auerbach 2008). Implicit assets may be regarded as a group of off-balance-sheet items that can potentially be converted into explicit government assets in the future and may help to restore fiscal sustainability in the long run, particularly when implicit liabilities (such as the implicit liabilities in the unfunded
PAYG pension pillar) start to materialise. Finally, there are also contingent assets which are contractual arrangements that specify one or more conditions which must be fulfilled before a financial transaction takes place, e.g. guarantees of payment by a third party, lines or letters of credit and certain derivative instruments.

The financial and economic crisis points to the need for a comprehensive government balance sheet approach, as also suggested by the IMF (2009b) (see Table 1). First, due to operations to stabilise the financial sector since 2008, government balance sheets have expanded and the composition and value of financial assets and liabilities have changed. Second, a wider spectrum of government liabilities could be taken into account (e.g. financial derivatives or other accounts payable - see Section 3.1) and financial asset positions might also be considered (as well as the net debt concept - see Section 3.3). Likewise, the stylised government balance sheet would also include data on government non-financial assets. Third, due consideration of off-balance-sheet assets and liabilities is necessary for assessing the potential risks to the sustainability of public finances (see Section 4).

\begin{tabular}{|c|c|c|}
\hline & $\begin{array}{l}\text { Financial assets } \\
\text { (government has a claim that somebody } \\
\text { else will pay to government) }\end{array}$ & $\begin{array}{l}\text { Liabilities } \\
\text { (government is obliged to pay } \\
\text { to somebody else) }\end{array}$ \\
\hline \multirow[t]{9}{*}{ Balance sheet items (ESA 95) } & Currency and deposits & Currency and deposits $(E D P$ debt) \\
\hline & Securities other than shares, excluding derivatives & $\begin{array}{l}\text { Securities other than shares, excluding derivatives } \\
(E D P \text { debt })\end{array}$ \\
\hline & Financial derivatives & Financial derivatives \\
\hline & Loans granted & Loans received (EDP debt) \\
\hline & Shares and other equity & \\
\hline & Insurance technical reserves & Insurance technical reserves \\
\hline & Other accounts receivable & Other accounts payable \\
\hline & Non-financial assets & Net worth (B.90) \\
\hline & $\begin{array}{l}\text { Produced fixed assets } \\
\text { Non-produced assets }\end{array}$ & \\
\hline \multirow[t]{2}{*}{ Off-balance-sheet items } & $\begin{array}{l}\text { Implicit assets (e.g. additional revenue stemming } \\
\text { from future taxes, broadening tax bases, increasing } \\
\text { social contributions) }\end{array}$ & $\begin{array}{l}\text { Implicit liabilities (e.g. unfunded PAYG pension } \\
\text { pillar) }\end{array}$ \\
\hline & Contingent assets & Contingent liabilities (e.g. guarantees) \\
\hline
\end{tabular}


In turn, this analysis is linked to the balance sheet approach, leading to a net worth concept

Government debt can be defined in different ways depending on the economic sector of reference, the liabilities being considered, and whether the liabilities are net of assets. In practice, the current measurement of government debt in the euro area is confined to the general government sector. In theory, there is the possibility of calculating the debt of the public sector ${ }^{10}$ in the euro area, which would also include the burden from public financial and non-financial corporations, ${ }^{11}$ but the application is still part of the research agenda and it is only due to be implemented with the new 2010 ESA transmission programme. ${ }^{12}$

Government debt is a stock variable which captures the flow of previous government deficits. On top of these deficits, there are also some additional transactions which do not alter the deficit, but do affect the government debt. The difference is known as the deficitdebt adjustment (DDA) or, generally, as the stock-flow adjustment (SFA). This perspective corresponds to an analysis of how government debt has originated over time. Government deficits are financed by government borrowings from the other sectors of the economy, i.e. a government issues liabilities in exchange for money while other sectors increase their claims vis-à-vis the government when they provide money. The structure of these government liabilities reveals, inter alia, who lends to the government, when their claims are due, in which currency the government needs to pay back its debt and whether or not the interest rate is fixed or conditional on some other economic variable, for example the money market interest rate or inflation. The outstanding government debt can be measured as the sum of government liabilities (this would lead to the concept of a gross debt) or these liabilities can be compared with, or adjusted by, the sum of financial assets which the government can use to liquidate its liabilities (this would lead to a net debt concept). An important question is which financial assets should or should not be taken into account (e.g. due to their marketability or liquidity). when financial as well as non-financial assets are taken into consideration.

The purpose of Section 3.1 is to present the two possible concepts of gross debt for the general government sector depending on the liabilities considered, namely EDP (or Maastricht) debt and ESA debt. Section 3.2 focuses on the developments in terms of government debt in the euro area countries. Moreover, Section 3.3 introduces and assesses the concept of net government debt, i.e. government debt net of financial assets held by the general government. Finally, Section 3.4 analyses the financial assets and the net government debt concept for the euro area countries.

\section{I GOVERNMENT LIABILITIES AND GOVERNMENT DEBT}

Overall, (gross) government debt consists of the explicit liabilities owed by general government. The two concepts of (gross) government debt presented below differ mainly in terms of the liabilities they include and their valuation. The focus of the definition remains on gross liabilities, i.e. excluding any government assets which can be used to liquidate the debt.

The first concept of government debt in the euro area countries, usually referred to as the

10 The public sector is not a separate unit in national accounts like the general government sector (S.13), but rather it is a grouping of sectors (S.13) and sub-sectors (public units from the non-financial corporations sector (S.11) and financial corporations sector (S.12), and the central bank (S.121). See the 2008 edition of the System of National Accounts, SNA 22.41.

11 To be classified as a public corporation, an institutional unit must be controlled by a government unit, another public corporation, or some combination of them, and sell most of its output at economically significant prices (2008 SNA 22.27). If a public unit is mainly financed by the general government according to its costs (prices that generate sales covering less than $50 \%$ of production costs - the $50 \%$ rule), the public unit has to be classified inside the general government sector.

12 ESA stands for European System of Accounts. The methodological and legal basis for the calculation of this extended measure of government debt is already in place and can be found in SNA 2008 (Chapter 22), ESA 2010 (Chapter 20) and the corresponding Table 6 from the forthcoming ESA 2010 transmission programme. 
Maastricht debt, is defined as the gross debt of general government at nominal value outstanding at the end of the year and consolidated at general government sub-sector level. It covers government liabilities in the form of currency along with deposits, loans and securities other than shares (see Table 1). The Maastricht debt excludes certain financial instruments, such as financial derivatives and trade credits. This concept of government debt is applied within the European fiscal framework of the Excessive Deficit Procedure (EDP) and is therefore also known as EDP debt. It is the relevant concept for procedural purposes in the EU. In particular, it is used for fiscal surveillance, under the SGP, to assess whether the criterion of a government debt ratio below the " $60 \%$ of GDP" reference value is met. The clear advantage of EDP debt is that no assumptions on the prices, marketability or liquidity of government assets need to be made. Thus, in periods of market turbulence, the prices and marketability of government assets may fluctuate and complicate the net debt concept's compilation, whereas gross debt remains a robust indicator. ${ }^{13}$ However, a direct comparison between EDP debt and international headline fiscal figures (e.g. the US and Japan) is not advisable without adjustments due to differences in their compilation methods (see Box 2).

A second definition of (gross) government debt is derived directly from the national accounts in line with the European System of Accounts 1995 (ESA 95) and is therefore referred to as ESA debt. Although there is no formal definition of ESA government debt in national accounts, in practice it covers all explicit government liabilities, excluding only equity (see Table 1$).{ }^{14}$ In addition to the instruments included in EDP debt, ESA debt also covers other financial instruments, namely financial derivatives, other accounts payable and insurance technical reserves, where applicable. As regards the valuation of liabilities, ESA debt as it appears on the balance sheet of general government is recorded at market value. Therefore the level of ESA debt is affected by changes in market yields, which is not the case for EDP debt, under which the financial instruments are measured at nominal value. Table 2 summarises

13 In particular, the EDP does not use any market prices for its calculation (i.e. EDP debt is recorded at nominal or face value).

14 The ESA "equity and other shares" category is excluded as most government units, with some minor exceptions, do not issue equity.

\begin{tabular}{|c|c|c|}
\hline & EDP debt & ESA debt \\
\hline Sector delineation & \multicolumn{2}{|c|}{ General government sector (S.13) } \\
\hline Gross concept & \multicolumn{2}{|c|}{$\begin{array}{l}\text { Gross debt (i.e. financial assets of the general government are not subtracted in the calculation } \\
\text { of EDP or ESA debt) }\end{array}$} \\
\hline Breakdown by financial instrument & $\begin{array}{l}\text { "EDP instruments": currency and deposits; } \\
\text { securities other than shares excluding } \\
\text { derivatives; loans }\end{array}$ & $\begin{array}{l}\text { "ESA debt instruments": financial derivatives; } \\
\text { other accounts payable; insurance } \\
\text { technical reserves }\end{array}$ \\
\hline Valuation rules & Nominal value & Market value \\
\hline Consolidation & $\begin{array}{l}\text { Consolidated (across the general government } \\
\text { sector) }\end{array}$ & $\begin{array}{l}\text { Dual presentation: non-consolidated and } \\
\text { consolidated(quarterly financial accounts } \\
\text { forthe general government sector) }\end{array}$ \\
\hline Main advantages & $\begin{array}{l}\text { - "EDP instruments" are valued in nominal } \\
\text { terms, avoiding market fluctuations in the } \\
\text { calculation of EDP debt } \\
\text { - Simplicity in the calculation of EDP debt } \\
\text { (mainly linked to the exclusion of liabilities } \\
\text { that are difficult to measure in practice) } \\
\text { - EDP debt is directly applicable only in the } \\
\text { EU context }\end{array}$ & $\begin{array}{l}\text { - ESA debt provides a more comprehensive } \\
\text { picture of government liabilities } \\
\text { - ESA debt allows the calculation of net debt, } \\
\text { as assets are also valued at market prices } \\
\text { - ESA debt facilitates international } \\
\text { comparisons, as government balance sheet } \\
\text { data are generally available and directly } \\
\text { comparable }\end{array}$ \\
\hline
\end{tabular}


Chart I Euro area government EDP and ESA debt, $1999-2012$

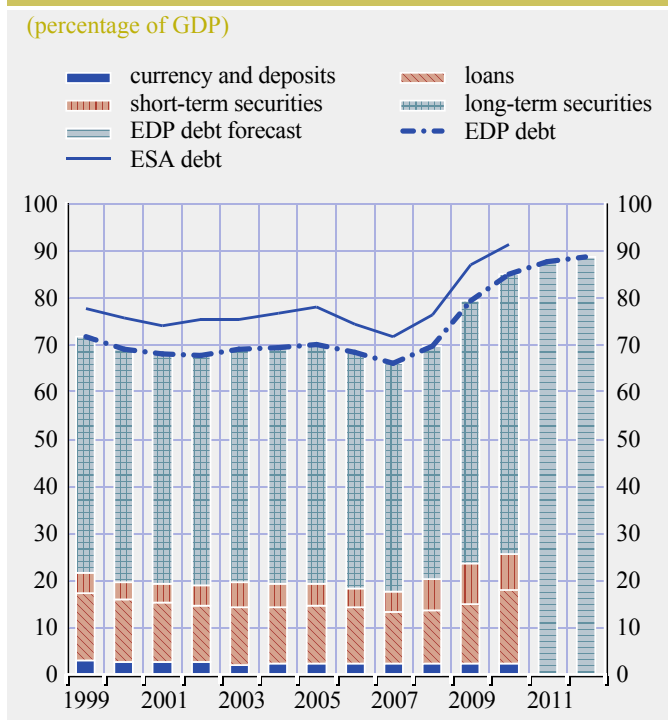

Source: ECB calculations (based on Eurostat and national data), European Commission Spring 2011 forecasts (EDP debt for 2011-12).

the methodological similarities and differences between the EDP and ESA debt concepts.

Chart 1 shows euro area average gross government debt-to-GDP ratios, within the meaning of both EDP debt and ESA debt, for the period 1999-2010. By end-2010, the euro area average EDP debt ratio amounted to $85.2 \%$ of GDP and the ESA debt ratio stood at $91.4 \%$ of GDP ${ }^{15}$ - the discrepancy can be attributed to methodological differences in instrument composition and valuation rules as illustrated in Table 2. Looking ahead, EDP debt is expected to reach $88.5 \%$ of GDP in 2012, with a subsequent proportional increase in the ESA debt ratio.

The stock of government debt in the euro area, either EDP debt or ESA debt, shows a growing accumulation of liabilities due to the unfavourable fiscal developments since 2007. In order to obtain a more detailed analysis of the reasons behind the increases in government debt ratios, equation (3) and Table 3 break down the change in the EDP debt ratio $\left(\mathrm{D}_{\mathrm{t}} / \mathrm{GDP}_{\mathrm{t}}\right)$ within the euro area into three contributing factors:

(i) nominal GDP growth (g);

(ii) general government deficit (expenditure revenue);

(iii) deficit-debt adjustments (DDA).

15 These amounts are calculated based on quarterly financial accounts (consolidated) for the general government sector.

\begin{tabular}{|c|c|c|c|c|c|c|c|}
\hline \multicolumn{8}{|c|}{ (as percentage of GDP) } \\
\hline & & 2007 & 2008 & 2009 & 2010 & $2011^{1)}$ & $2012^{1)}$ \\
\hline 1 & General government gross debt ${ }^{2}$ & 66.2 & 69.9 & 79.3 & 85.2 & 87.7 & 88.5 \\
\hline & $\begin{array}{l}\text { Change in debt ratio }(2=3+4+5) \\
\text { of which contribution of: }\end{array}$ & -2.3 & 3.6 & 9.5 & 6.0 & 2.4 & 0.8 \\
\hline 3 & Nominal GDP growth & -3.5 & -1.6 & 2.3 & -2.0 & -2.5 & -2.9 \\
\hline 4 & General government deficit $(4=4 a+4 b)$ & 0.7 & 2.0 & 6.3 & 6.0 & 4.3 & 3.5 \\
\hline $4 a$ & Automatic stabilisers & -1.0 & -0.5 & 2.0 & 1.6 & 1.3 & 1.0 \\
\hline & Other & 1.7 & 2.5 & 4.3 & 4.4 & 3.0 & 2.5 \\
\hline 5 & Deficit-debt adjustment $(5=5 \mathrm{a}+5 \mathrm{~b})$ & 0.5 & 3.2 & 0.9 & 1.9 & 0.6 & 0.2 \\
\hline $5 a$ & Of which support to financial sector & 0.0 & 1.9 & 0.5 & 2.5 & . & \\
\hline & Of which other deficit-debt adjustment & 0.5 & 1.3 & 0.4 & -0.6 & . & \\
\hline
\end{tabular}

Sources: ECB and European Commission.

1) European Commission Spring 2011 forecasts (EDP debt for 2011-12, intergovernmental lending in the context of the financial crisis is 1) European Commission Spring 2011 forecasts (EDP debt for 2011-12, intergovernmental lending in the context of the financial crisis is not consolidated)

2) Data refer to EDP debt. General government gross debt at nominal value and consolidated between sub-sectors of government. For 2010, intergovernmental lending in the context of the sovereign debt crisis is consolidated. 
The latter item includes operations which affect the government debt level without being recorded in the deficit (e.g. debt-financed acquisition of financial assets).

$$
\Delta \frac{D_{t}}{G D P_{t}} \approx \frac{E X P_{t}-R E V_{t}}{G D P_{t}}+\frac{D D A_{t}}{G D P_{t}}-\frac{g}{1+g} \cdot \frac{D_{t-1}}{G D P_{t}}
$$

Looking at the period 2007-10, the following observations may be derived. First, the role of nominal GDP growth - which is the denominator in the debt-to-GDP ratio - was a factor in increasing the debt in 2009 because of the contracting economy, but otherwise it was a factor in reducing the debt ratio between 2007 and 2010 due to positive nominal growth. Second, the debt-ratio increase reflects the deficit deterioration during the period 2008-10 in the euro area, mainly due to adopting sizeable fiscal stimulus measures on top of a significant fiscal impulse provided by automatic stabilisers, revenue shortfalls and structural spending growth (see Afonso et al., 2010) which contributed to stabilising the otherwise sharply contracting European economy. Third, the high and positive values of the deficit-debt adjustments in the course of 2007-10 reflect the fact that the government debt-to-GDP ratio increased more than implied by the deficits, primarily due to the financial transactions undertaken by government to support ailing financial institutions in the wake of the financial crisis $(1.9 \%$ of GDP in $2008 ; 0.5 \%$ of GDP in $2009 ; 2.5 \%$ of GDP in 2010), which are recorded "below the line" and therefore do not impact on the deficit.

The projected rise of the euro area government debt-to-GDP ratio for 2011 and 2012 is expected to be more moderate than the sharp debt accumulation at the peak of the economic and financial crisis in 2008-10. This reflects the lower accumulation of deficits as a result of the planned measures, the improved nominal GDP growth prospects and the smaller deficit-debt adjustments. However, the debt outcomes for 2011 and 2012 may differ from these projections, depending on the execution of budgetary plans as well as actual macroeconomic and financial developments.

\subsection{GOVERNMENT DEBT IN THE EURO AREA COUNTRIES}

A common starting point for the assessment of sustainability risks is to examine a country's (explicit) government debt-to-GDP ratio. This is because high and rising government debt ratios indicate potential sustainability problems. Table 4 shows the evolution of the government debt-to-GDP ratio in the euro area countries. By the end of 2010, debt-to-GDP ratios in most euro area countries and the euro area as a whole exceeded the $60 \%$ reference value (the exceptions being Estonia, Luxembourg, Slovenia, Slovakia and Finland, while Spain and Cyprus were just above the $60 \%$ reference value). Looking ahead, the picture deteriorates further as the government debt ratio for the euro area countries is expected to continue its rise by 2012 , with the exception of Germany and Malta. Moreover, Table 4 shows that for most euro area countries the accumulation of debt has to a large extent intensified during the crisis. Credible fiscal consolidation strategies are needed to stabilise government growth ratios in the short term in order to put them on a sustainable path. Experience during the period 1999-2007 showed that sizeable debt reductions were feasible, for example in Belgium, Ireland, Spain, Italy, the Netherlands, Slovakia and Finland.

Looking more closely at the composition of EDP debt by country, Table 5 shows that euro area countries issued extensive securities in 2010. In particular, long-term securities represented over $60 \%$ of total EDP debt for all countries, with the two exceptions of Estonia and Luxembourg. The second most important instrument are loans, and this is particularly true for Estonia (almost $75 \%$ of the total), Luxembourg (about 45\%), Germany and Cyprus (around 30\%). Finally, the contribution of currency and deposits to total EDP debt is marginal, with the exceptions of Ireland and Italy (both around 9\%) and Portugal (just above $7 \%$ of the total). 


\begin{tabular}{|c|c|c|c|c|c|c|c|}
\hline \multicolumn{8}{|c|}{ (as percentage of GDP) } \\
\hline & 1999 & 2007 & 2010 & $\begin{array}{r}2011^{1)} \\
\text { (forecast) }\end{array}$ & $\begin{array}{r}2012^{1)} \\
\text { (forecast) }\end{array}$ & $\begin{array}{r}\text { EDP debt } \\
\text { accumulation } \\
(1999-2007)\end{array}$ & $\begin{array}{r}\text { EDP debt } \\
\text { accumulation } \\
(2007-2012)\end{array}$ \\
\hline Belgium & 113.7 & 84.2 & 96.8 & 97.0 & 97.5 & -29.5 & 13.3 \\
\hline Germany & 60.9 & 64.9 & 83.2 & 82.4 & 81.1 & 4.0 & 16.1 \\
\hline Estonia & 6.5 & 3.7 & 6.6 & 6.1 & 6.9 & -2.8 & 3.2 \\
\hline Ireland & 48.2 & 25.0 & 96.2 & 112.0 & 117.9 & -23.2 & 92.9 \\
\hline Greece & 100.3 & 105.4 & 142.8 & 157.7 & 166.1 & 5.1 & 60.7 \\
\hline Spain & 62.3 & 36.1 & 60.1 & 68.1 & 71.0 & -26.2 & 34.9 \\
\hline France & 58.8 & 63.9 & 81.7 & 84.7 & 86.8 & 5.1 & 22.9 \\
\hline Italy & 113.7 & 103.6 & 119.0 & 120.3 & 119.8 & -10.1 & 16.2 \\
\hline Cyprus & 58.9 & 58.3 & 60.8 & 62.3 & 64.3 & -0.6 & 6.0 \\
\hline Luxembourg & 6.4 & 6.7 & 18.4 & 17.2 & 19.0 & 0.2 & 12.4 \\
\hline Malta & 57.1 & 62.0 & 68.0 & 68.0 & 67.9 & 4.8 & 5.9 \\
\hline Netherlands & 61.1 & 45.3 & 62.7 & 63.9 & 64.0 & -15.8 & 18.7 \\
\hline Austria & 67.3 & 60.7 & 72.3 & 73.8 & 75.4 & -6.6 & 14.7 \\
\hline Portugal & 49.6 & 68.3 & 93.0 & 101.7 & 107.4 & 18.7 & 39.1 \\
\hline Slovenia & 24.3 & 23.1 & 38.0 & 42.8 & 46.0 & -1.2 & 22.9 \\
\hline Slovakia & 47.8 & 29.6 & 41.0 & 44.8 & 46.8 & -18.3 & 17.2 \\
\hline Finland & 45.7 & 35.2 & 48.4 & 50.6 & 52.2 & -10.5 & 17.0 \\
\hline Euro area ${ }^{2)}$ & 71.7 & 66.2 & 85.2 & 87.7 & 88.5 & -5.5 & 22.3 \\
\hline
\end{tabular}

Sources: European System of Central Banks (ESCB), European Commission (observations published by Eurostat in its News Release 60/2011 of 26 April 2011; European Commission Spring 2011 forecasts (EDP debt for 2011-12).

1) European Commission projections do not include the impact of the activation of the EFSF in the context of financial support to Ireland. Intergovernmental lending in the context of the financial crisis is not consolidated.

2) Data refer to EDP debt. Gross general government debt at nominal value and consolidated between sub-sectors of government. For 2010, intergovernmental lending in the context of the financial crisis is consolidated.

\section{Table 5 General government EDP debt by financial instruments $(2010)$}

(as percentage of total)

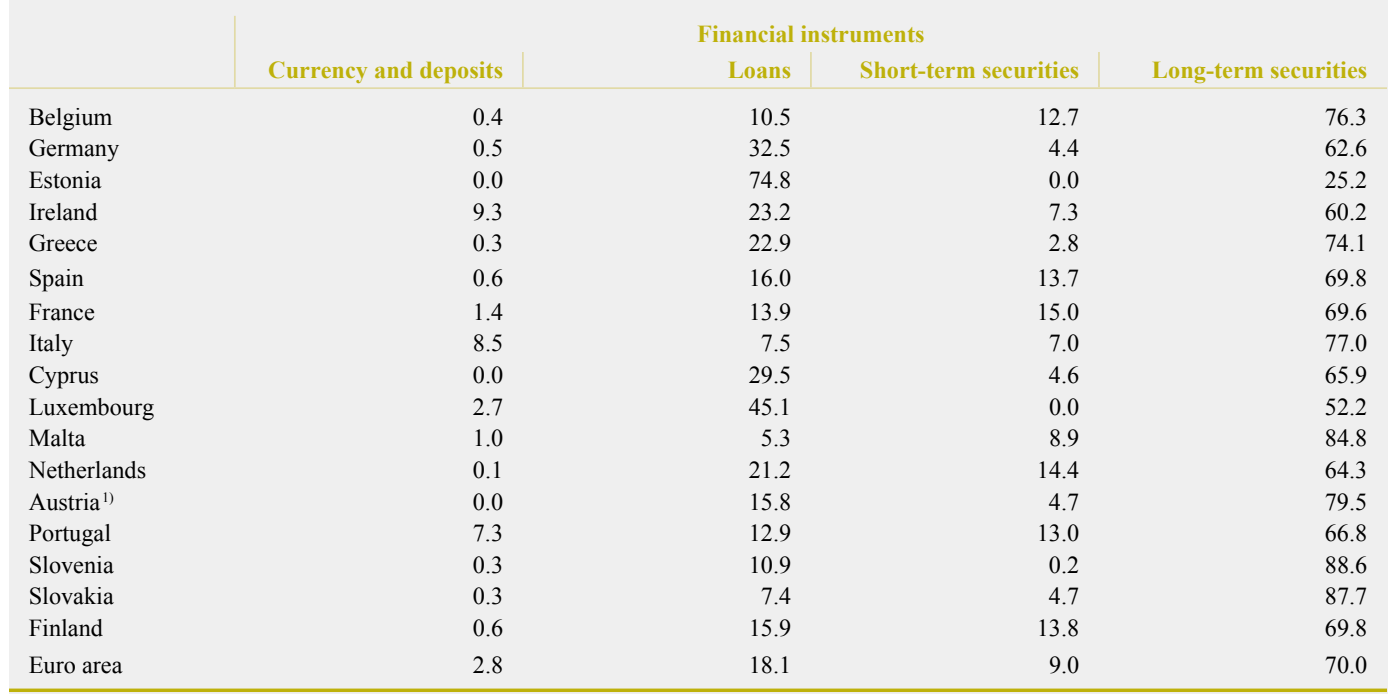

Source: ECB calculations (based on Eurostat and national data).

1) Data refer to 2009. 
Box I

\section{HISTORICAL GOVERNMENT DEBT IN THE SELECTED EURO AREA COUNTRIES}

The chart presents government debt series consistent with the European system of accounts, although possible methodological inconsistencies intrinsic to such lengthy time series may persist. One advantage is that the reference sector is the general government whereas available historical and lengthy time series normally refer only to the central government sub-sector, such as the data accessible in the IMF database. Moreover, some statistical data sources at national level exist for debt series before 1900, e.g. historical debt data in Italy are available from 1861 (Francese and Pace, 2008) and in the Netherlands from 1814 onwards (Bos, 2007).

Several euro area countries have experienced periods of high government indebtedness in the past, and most significant debt reductions were feasible when adequate economic policies were in place. This is illustrated in the chart for the sample of the five biggest euro area countries.

In particular, the Netherlands was able to

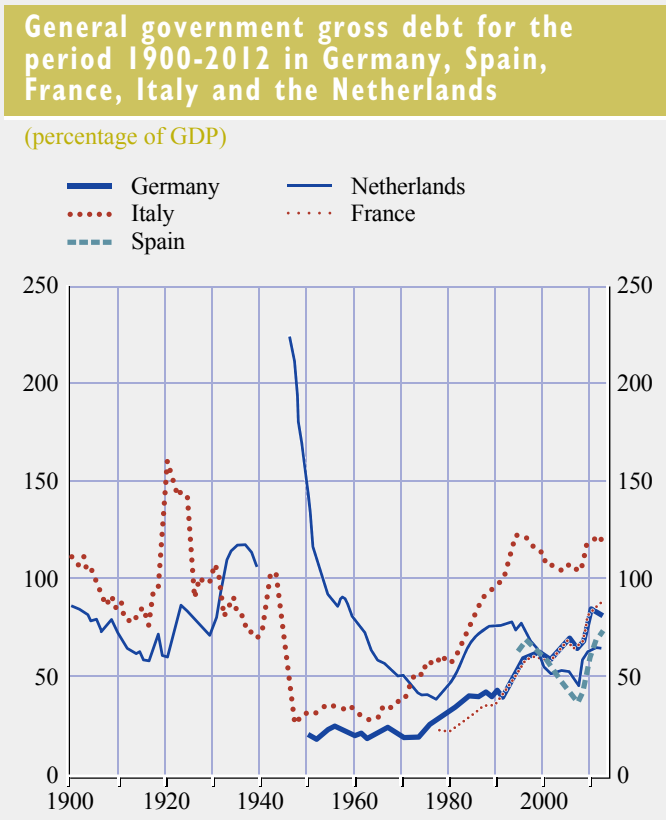

Source: ECB calculations based on the following data sources: Germany - debt statistics (West Germany for 1950-90 DESTATIS from 1991 onwards); Spain - INE (from 1995 onwards); France - INSEE (from 1978 onwards); Italy Banca d'Italia (1900-94), ISTAT (from 1995 onwards); the Netherlands - Centraal Planbureau (from 1900 onwards); 2011-12 projection from the European Economic Forecast (Spring 2011). reduce its general government debt by around 138 p.p. of GDP in just ten years (1946-56) mainly due to sustained growth as well as to an accumulation of two-digit government surpluses (1948-50). Likewise, Italy experienced high debt ratios, exceeding $160 \%$ of GDP in 1920 , which were contained to around $100 \%$ of GDP in 1945. Although no comparable historical data are available for France before 1978, data shown in Reinhart and Rogoff's seminal work $(2008,2009)$ suggest that the central government debtto-GDP ratios also reached high levels in the 1920 s, possibly in excess of $200 \%$ of GDP. More recently, the period just before the introduction of the euro, in which countries also had to qualify based on the EDP debt-to-GDP ratio indicator, was characterised by a significant consolidation effort that put the debt ratios on declining paths. As a result, the Netherlands, Spain and Italy witnessed a significant reduction in their government debt-to-GDP ratio (by roughly 30 p.p. and 20 p.p. of GDP in the latter case) during the decade starting from the mid-1990s.

\subsection{GOVERNMENT ASSETS AND NET GOVERNMENT DEBT}

In the euro area, the market value of government financial assets represents more than one-third of the value of government liabilities. From a solvency perspective, it is also important therefore to take assets into account when assessing government debt levels. Government financial assets include currency and deposits, loans granted by government, securities other than shares, shares and other equity, insurance technical reserves and other accounts receivable (see Table 1) measured in market value in 


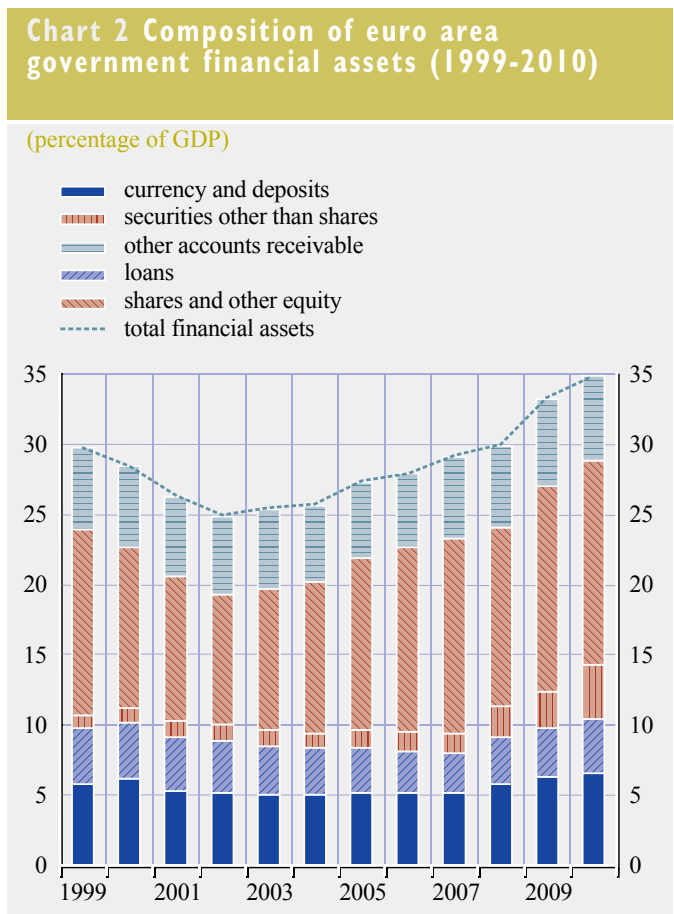

Source: ECB calculations (based on Eurostat and national data).

accordance with ESA 95 methodology. Focusing simply on gross government debt may provide an incomplete picture, particularly when the increase in government liabilities is accompanied by a simultaneous increase in government assets. In this sense, the governments in the euro area have steadily accumulated financial assets since 2003, with relative growth in the stock of financial assets of $5.5 \%$ of GDP in 2010 compared to 2007. In 2010, total financial assets held by governments in the euro area, on a consolidated basis, represented almost $35 \%$ of GDP, of which $4.8 \%$ of GDP was estimated to be directly related to the financial crisis. ${ }^{16}$ This mainly involved the acquisition of financial assets such as currency and deposits (via borrowing), loans and equity. Changes in currency and deposits reflect the reinforcement in some countries of cash reserves by issuing bonds or engaging in loans (recorded as government debt). Changes in securities other than shares basically reflect the net purchases by government of securities issued by financial institutions ${ }^{17}$ or the investment in securities by pension institutions. ${ }^{18}$ Likewise, the growth in shares and other equity reflects equity injections in ailing financial institutions in many countries ${ }^{19}$ or portfolio investments, particularly in assetrich social security funds.

Table 6 illustrates that the main contributor to the change in the assets-to-GDP ratio in 2008 and 2010 was support to the financial sector, while in 2009 strong negative growth chiefly explained the change in the asset ratio within the euro area. In other words, there was parallel accumulation of financial assets and liabilities during the period 2008-10, which was associated in part with support to the financial sector.

In a further step, it can be relevant to examine an indicator of net government debt as a complementary source of information for analysing solvency, whereby the market value of financial assets held by government is subtracted from the market value of liabilities. ${ }^{20}$ In practice, the calculation of net debt can be derived as the arithmetic difference between the stock of government liabilities, or ESA debt, and the stock of government financial

16 The conduct of government interventions in the banking sector since 2008 via recapitalisations (capital injections: acquisition of shares and loans), debt cancellation and the purchase or exchange of assets, resulted in an estimated amount of outstanding assets of $1.9 \%$ of GDP in $2008,2.3 \%$ of GDP in 2009 and $4.8 \%$ of GDP in 2010.

17 It mainly applies to the cases of Belgium, Germany, the Netherlands and Ireland. The case of Germany reflects the purchases of securities by SPEs (bad banks) classified within general government in 2008 and the purchases of impaired assets by EAA and HRE FMSW (11.1\% of GDP) in 2010. In the case of Ireland (2009) it mainly reflects capital injections, in the form of promissory notes (treated as loans on the liabilities side of the government balance sheet, following the nationalisation of Anglo Irish Bank, Allied Irish Bank and Bank of Ireland. In the case of the Netherlands (2009) it reflects the recapitalisation of ABN AMRO through mandatory convertible notes and capital relief instruments.

18 This was the case with Finland in 2008 (accumulation of financial assets in the Social Security Fund) and also the case with Ireland in 2008 (accumulation of financial assets by the Irish National Pension Reserve Fund - reversed in 2010 as a consequence of the agreed bailout package, see footnote 29).

19 Belgium (2008-09), Germany (2008-10), Greece (2009), Luxembourg (2008-09), the Netherlands (2008), Austria (2009) and Finland (2009).

20 As a next forward step, it would also be necessary to measure so-called government net worth, defined as the balancing item of total government (financial and non-financial) assets and liabilities (see Milesi-Ferretti and Moriyama, 2004). However, this is currently not feasible for the euro area given the unavailability of data on government non-financial assets. 


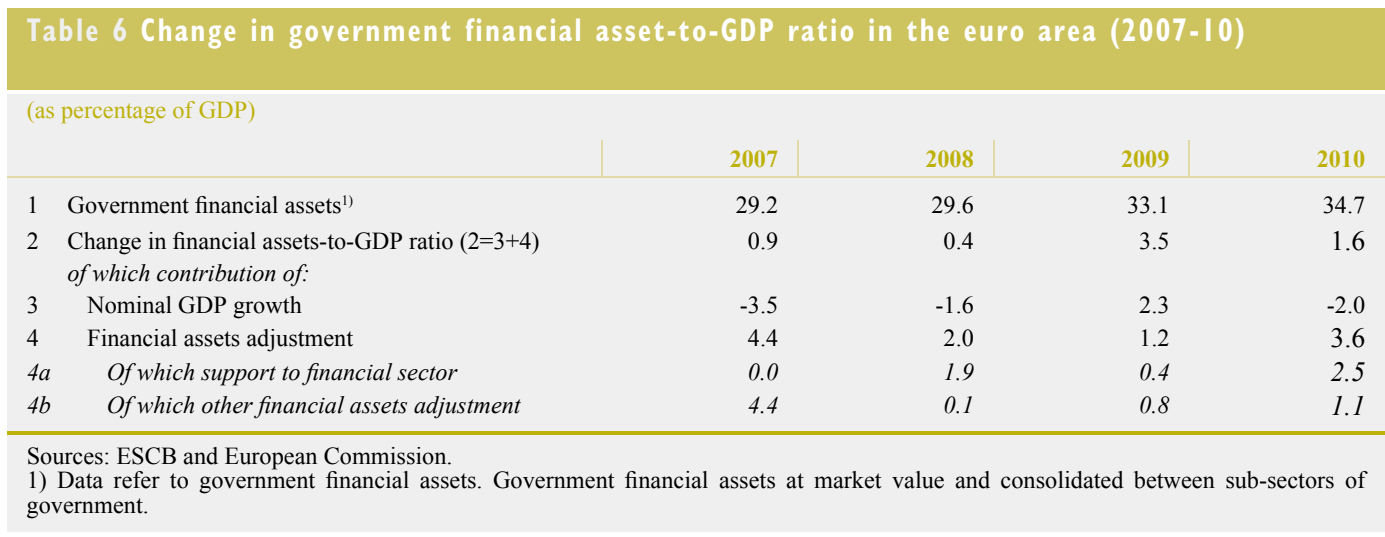

assets at a given year (see Mink and RodríguezVives, 2004). As shown in Chart 3, average net government debt hovered at around $50 \%$ of GDP in the last decade and increased to $56.7 \%$ of GDP in 2010. This implies that in the euro area, the market value of government liabilities is more than twice as large as the market value of government financial assets.

In principle, government financial assets represent to some extent a buffer for the euro area since governments could sell their assets to redeem debt. In practice, however, there is a difficulty in ascertaining a priori the extent to

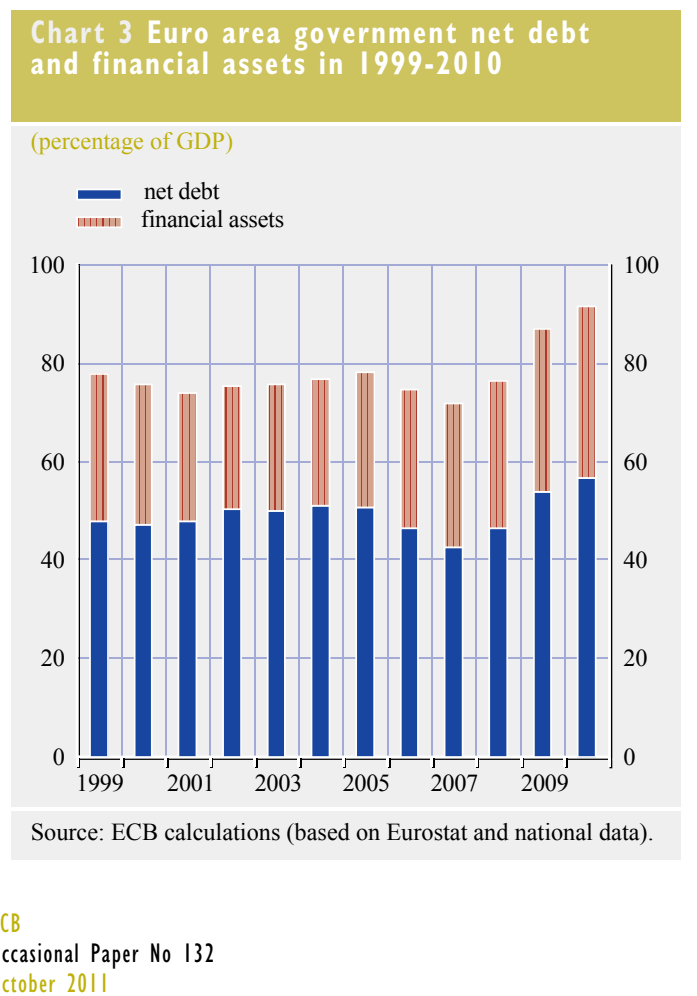

which assets might be rendered usable to meet outstanding government debt as not all assets are equally liquid. For example, some shares and other equity invested in public corporations are illiquid and cannot be quickly mobilised to redeem debt. Short-term financial assets, which are supposed to be liquid, include currency and deposits, short-term debt securities, short-term loans and other accounts receivable. Another limitation is the probability of liquidating the financial asset without incurring (major) losses. An example is represented by the assets acquired by governments in the context of the financial crisis ${ }^{21}$ since their market value is uncertain and it may turn out to be well below face value. Another consideration is to decide, on the assumption that governments should seek to repay debt as their first priority when selling assets, ${ }^{22}$ what the best operational strategy is for repaying such debt, i.e. to use the proceeds against refinancing needs as they mature or to achieve a new debt portfolio structure based on debt management strategy (see IMF, 2009).

21 Asset purchases involve the acquisition of existing (possibly impaired) assets from financial institutions. The market value of some assets may be difficult to determine. In this respect, Eurostat has decided on a specific "decision tree" for valuing securities. In short, if the purchase price paid by government is above the market price (the latter being determined as the price either on an active market, or at an auction, or determined by the accounting books of the seller, or by a valuation of an independent entity), a capital transfer for the difference between the purchase price and the market price has to be recorded. If the assets are sold later, under similar market conditions, but at a lower price than the purchase price paid by government, the price difference should be recorded as a capital transfer.

22 Instead of considering other alternatives such as increasing expenditure, cutting taxes or purchasing other assets. 


\subsection{GOVERNMENT ASSETS AND NET DEBT IN THE EURO AREA COUNTRIES}

The key message from the previous section is that government financial assets have been growing in the euro area since the start of the crisis, in parallel with the increases in gross government debt. In Table 7 this message is reinforced when looking at developments per euro area country. With few exceptions (i.e. Cyprus, Slovenia, Slovakia), the euro area countries have mostly increased, or at least maintained (France, Malta), their holdings in financial assets for the period 2007-10. This particularly applies to Ireland with a cumulative increase of total financial assets of $14 \%$ of GDP, and to Slovenia with a cumulative decrease of total financial assets of around 7\% of GDP for the period 2007-10.

Overall, end-2010 figures showed that the majority of countries have accumulated financial assets with values ranging between $30 \%$ and $40 \%$ of GDP. However, there is a group of countries with relatively low values, at or below $25 \%$ of GDP, comprising Belgium, Spain, Cyprus and Slovakia. At the other extreme, Estonia, Ireland and Slovenia have assets worth above $40 \%$ of
GDP - although in the case of Ireland part of these financial assets will be liquidated as agreed in the EU/IMF bailout package (see footnote 29) while Finland and Luxembourg, traditionally asset-rich countries, had financial assets of over $60 \%$ of GDP by end- 2010 .

Looking more closely at the composition of financial assets by country, Table 8 shows that a majority of countries held significant amounts of shares and other equity in their asset portfolios in 2010 (at or above $40 \%$ of total financial assets) with the exception of Germany, Ireland, Spain and Italy. Moreover, some countries have relatively large percentages of currency and deposits in their asset portfolios. This short-term liquid asset is particularly high for Germany, Ireland, Spain, Cyprus and Malta (between 28\% and $35 \%$ of the total). Another short-term asset, other accounts receivable, represents a relatively high percentage of total financial assets in the cases of Belgium, Greece, France, Italy, Malta and the Netherlands (between 20 and 30\%). Finally, securities are particularly relevant for Germany ( $20 \%$ of the total) and Finland (18\%), while loans are significant in the asset portfolios of the Netherlands $(22 \%$ of the total) and Austria (25\%).

\begin{tabular}{|c|c|c|c|c|}
\hline \multicolumn{5}{|c|}{ (percentage of GDP) } \\
\hline & 2007 & 2008 & 2009 & 2010 \\
\hline Belgium & 14.8 & 19.4 & 20.3 & 20.0 \\
\hline Germany & 23.2 & 25.4 & 28.5 & 36.8 \\
\hline Estonia & 36.9 & 34.5 & 41.5 & 47.3 \\
\hline Ireland & 29.0 & 37.1 & 44.9 & 43.3 \\
\hline Greece & 32.4 & 27.2 & 31.0 & 33.1 \\
\hline Spain & 23.4 & 24.2 & 27.6 & 25.9 \\
\hline France & 37.5 & 35.0 & 40.0 & 37.4 \\
\hline Italy & 25.7 & 25.3 & 27.4 & 27.6 \\
\hline Cyprus & 27.6 & 21.3 & 24.6 & 23.1 \\
\hline Luxembourg & 65.9 & 68.4 & 71.9 & 67.7 \\
\hline Malta & 30.4 & 27.2 & 30.4 & 30.5 \\
\hline Netherlands & 23.7 & 37.7 & 37.8 & 36.9 \\
\hline Austria & 32.2 & 33.6 & 33.9 & 34.6 \\
\hline Portugal & 25.8 & 26.6 & 28.8 & 34.3 \\
\hline Slovenia & 47.6 & 35.4 & 44.1 & 40.3 \\
\hline Slovakia & 25.5 & 22.9 & 22.7 & 24.1 \\
\hline Finland & 114.0 & 93.0 & 115.4 & 121.2 \\
\hline Euro area & 29.2 & 29.6 & 33.1 & 34.7 \\
\hline
\end{tabular}

Source: ECB calculations (based on Eurostat and national data) 


\begin{tabular}{|c|c|c|c|c|c|c|}
\hline \multicolumn{7}{|c|}{ (pencentage of total) } \\
\hline & \multicolumn{6}{|c|}{ Financial instruments } \\
\hline & $\begin{array}{r}\text { Currency and } \\
\text { deposits }\end{array}$ & Securities & Loans & $\begin{array}{r}\text { Shares and } \\
\text { other equities }\end{array}$ & $\begin{array}{r}\text { Other accounts } \\
\text { receivable }\end{array}$ & Other assets \\
\hline Belgium & 15.2 & 1.0 & 3.3 & 57.7 & 22.8 & 0.0 \\
\hline Germany & 28.4 & 20.5 & 14.6 & 28.9 & 9.2 & -1.6 \\
\hline Estonia & 11.6 & 13.7 & 3.0 & 58.9 & 12.7 & 0.0 \\
\hline Ireland & 32.4 & 15.1 & 5.5 & 33.7 & 12.4 & 0.9 \\
\hline Greece & 21.8 & 1.0 & 1.6 & 49.3 & 26.3 & 0.1 \\
\hline Spain & 34.5 & 11.4 & 12.8 & 34.5 & 6.7 & 0.0 \\
\hline France & 5.0 & 4.7 & 5.6 & 57.1 & 26.8 & 0.7 \\
\hline Italy & 21.8 & 4.6 & 13.6 & 28.9 & 30.7 & 0.4 \\
\hline Cyprus & 29.1 & 0.0 & 14.7 & 45.9 & 10.4 & 0.0 \\
\hline Luxembourg & 18.5 & 0.8 & 2.1 & 69.9 & 8.7 & 0.0 \\
\hline Malta & 30.6 & 0.0 & 3.3 & 44.6 & 21.5 & 0.0 \\
\hline Netherlands & 7.9 & 8.3 & 21.7 & 39.5 & 21.7 & 0.9 \\
\hline Austria & 13.0 & 7.9 & 24.6 & 46.9 & 6.9 & 0.6 \\
\hline Portugal & 12.9 & 3.1 & 7.3 & 59.1 & 17.4 & 0.2 \\
\hline Slovenia & 24.0 & 2.1 & 2.6 & 56.4 & 14.8 & 0.1 \\
\hline Slovakia & 21.1 & 1.2 & 8.2 & 62.8 & 6.7 & 0.0 \\
\hline Finland & 7.2 & 17.9 & 12.3 & 57.4 & 4.2 & 1.1 \\
\hline Euro area & 18.9 & 11.4 & 11.3 & 41.9 & 16.6 & -0.1 \\
\hline
\end{tabular}

Source: ECB calculations (based on Eurostat and national data).

Note: Other assets mainly cover monetary gold (F.11), special drawing rights (F.12), transactions related to the net acquisition of insurance technical reserves (F.6) and transactions in financial derivatives (F.34) including inflows and outflows related to purchases and sales of and settlements under options and warrants. Germany's negative value for other assets is due to negative transactions in financial derivatives.

\section{Box 2}

\section{GOVERNMENT DEBT IN THE US AND JAPAN}

A direct comparison of government financial statistics between the euro area and the US and Japan is not possible without adjustments due to methodological differences in their compilation. In particular, in order to compile government debt indicators for the US and Japan comparable to the "EDP debt" concept applied in the EU, additional reconciliation efforts are needed in terms of instrument coverage (EDP debt is a sub-set of total government liabilities, see Table 1), consolidation rules and sector delineation (in the US and Japan, the criteria used to decide if a unit is market or non-market and therefore should be part of the government sector is not based on clear rules such as the ESA 50\% rule). This 50\% rule determines that public enterprises in which a government subsidy represents $50 \%$ of total revenues or more are classified within the general government sector. In Japan, the deficit and debt indicators are compiled according to SNA 2008 concepts. US deficit data are based on the National Income and Products Accounts (NIPA) methodology, which deviates to some extent from SNA 2008, while US debt data are based on the Flow of Funds methodology used by the Federal Reserve.

In Chart A, comparable figures on government debt are compiled following the "EDP debt" definition covering government liabilities such as currency and deposits, securities other than shares (excluding financial derivatives) and loans. Comparable data show an increase in the debtto-GDP ratio between 2007 and 2010 in the euro area and the US, amounting to around 19 p.p. 


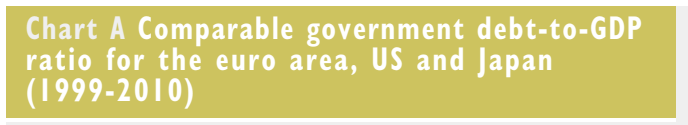

(percentage of GDP

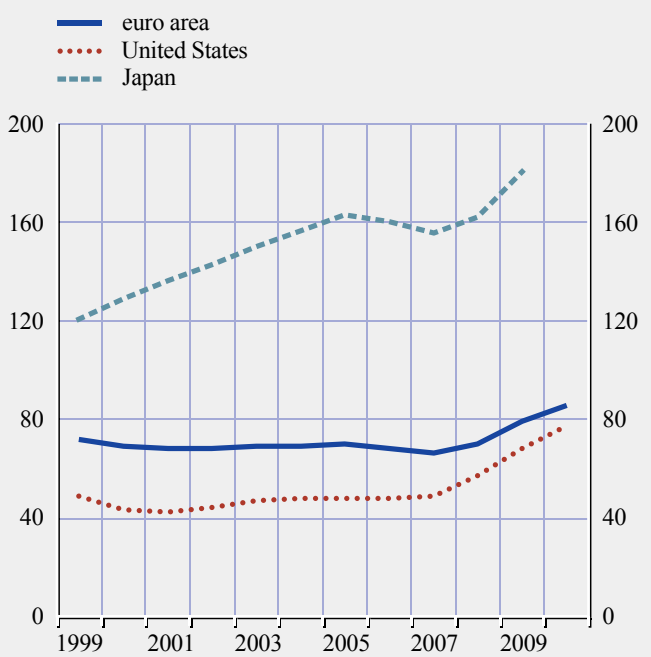

Source: ECB (based on Federal Reserve Board, Japan Cabinet Office data and Bank of Japan), 2010 data for Japan were not available.

\section{Chart B Financial assets and net debt for the euro area, US and Japan (2007-2010)}

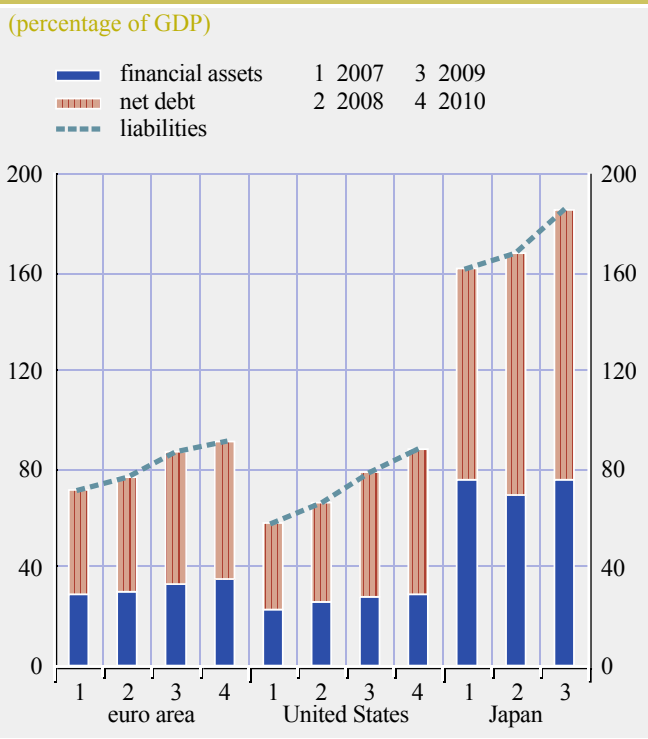

Source: ECB (based on Federal Reserve Board, Japan Cabinet Office data and Bank of Japan); 2010 data for Japan were not available.

and 29 p.p. respectively. In Japan, the government debt ratio stood at $180.4 \%$ of GDP in 2009 after rising by around 60 p.p. in the last decade, mainly due to the accumulation of high deficits and low GDP growth.

Chart B depicts financial assets and net debt for the euro area, US and Japan in 2007-10. The Japanese general government held financial assets worth just over 75\% of GDP in 2009 (with a high percentage, more than $50 \%$ of the total, held by its social security system), representing a solvency buffer. Government total liabilities (around 186\% of GDP) are calculated from Japan's balance sheet data, where total government liabilities include currency and deposits, loans, securities other than shares (including financial derivatives), shares and other equities and accounts payable. This yielded a net government debt-to-GDP ratio in Japan of around 110\% in 2009. In the US, financial assets represented about $29 \%$ of GDP in 2010 , with $65 \%$ of the total held by its state and local administrations. The total liabilities of the general government sector amounted to around $88 \%$ of GDP, with roughly $85 \%$ of the total belonging to the federal government. The resulting net debt in the US (approximately $58 \%$ of GDP in 2010) is therefore of similar magnitude to the net debt value obtained in the euro area.

While the average amount of financial assets held by governments in the euro area on average was roughly $35 \%$ of GDP in 2010 , the ratio of assets-to-GDP differs from country to country, making the relative buffer that asset positions bring to the growing debt burden rather heterogeneous. Chart 4 illustrates developments of government assets together with net debt in the euro area countries for the period 2007-10. Overall, the growth of financial assets is somewhat erratic between the countries. Most countries show either gradual and steady growth in financial assets for the period 2007-10 (e.g. Germany), albeit not enough to offset growing government (ESA and EDP) debt, or a fairly stable pattern (e.g. France, 
Chart 4 Financial assets and the ESA debt of euro area countries (2007-10)

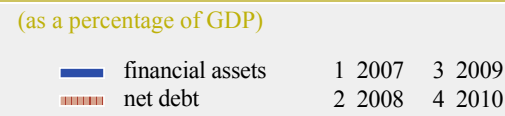

financial assets

net debt

$12007 \quad 32009$

$22008 \quad 42010$

n=w- liabilities

140 - 140

\begin{tabular}{l|l|l|l|l|l|l|l|}
140 \\
120
\end{tabular}

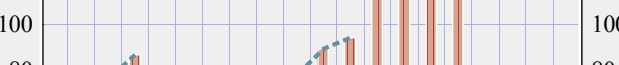

80

60

20

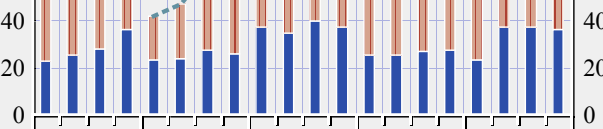

$\begin{array}{lllllllllllllllllll}1 & 2 & 3 & 4 & 1 & 2 & 3 & 4 & 1 & 2 & 3 & 4 & 1 & 2 & 3 & 4 & 1 & 2 & 3\end{array}$

Germany Spain France Italy Netherlands

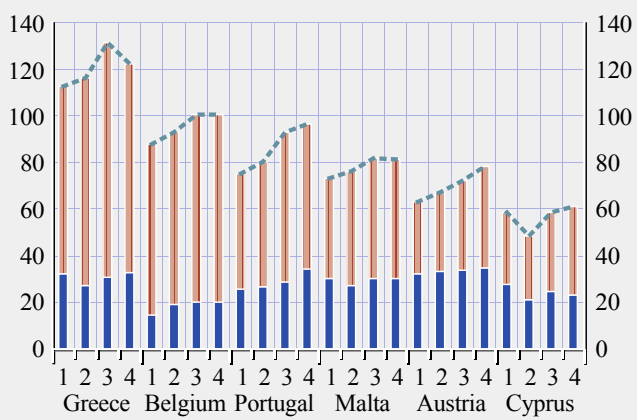

Greece Belgium Portugal Malta Austria Cyprus

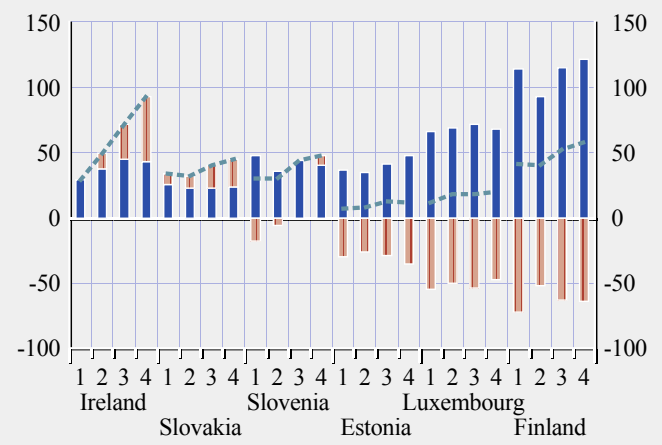

Source: ECB calculations (based on Eurostat and national data). Annex 2 provides a detailed table containing data for financial assets per country over the period 2007-10.

Italy or Spain), resulting in mounting net debt ratios. In contrast, some countries (especially the Netherlands and Ireland) experienced a sharp jump in financial assets in 2008, mostly due to government interventions undertaken to stabilise the financial sector, which helped to balance the parallel growth in government liabilities. The resulting net debt-to-GDP ratios vary considerably, depending on the size of government financial assets and liabilities. While many countries show net debt values of around $40 \%$ of GDP, the spectrum ranges from ratios above $80 \%$ of GDP (Belgium, Greece, Italy) to net debt of under $8 \%$ of GDP in Slovenia, or even to negative net-to-GDP debt values in the exceptional cases of Estonia, Finland and Luxembourg. 


\section{OFF-BALANCE-SHEET ASSETS AND LIABILITIES}

The ESA 95 methodological framework does not record a government's implicit and contingent assets and liabilities in government balance sheets. However, these assets and liabilities may turn explicit in the future and affect government debt (EDP or ESA debt). In particular, these implicit and contingent assets and liabilities may provide valuable information when judging the long-term sustainability of public finances, as explained in Section 2.

Since these off-balance-sheet components may be substantial, the main purpose of this section is to provide some numeric quantification of these within the euro area. As explained in Section 2, contingent liabilities are liabilities that may or may not be incurred depending on the outcome of a future event whereas implicit liabilities are non-contractual commitments of government vis-à-vis its citizens.

Section 4 aims to provide an overview of the assets and liabilities not recorded in national accounts, representing off-balancesheet positions of the general government sector and not accounted for in the explicit (gross or net) debt indicators. In particular, sub-section 4.1 provides some estimates of contingent liabilities, while sub-section 4.2 focuses on the implicit liabilities as well as making reference to the implicit assets.

\section{I CONTINGENT LIABILITIES}

A typical example of contingent liabilities is offered by the guarantee schemes provided by governments to secure bank liabilities. The support to the financial sector can take the form of guarantees to secure inter-bank lending and to secure debt issued by specialpurpose entities (SPEs), also known as 'bad banks'. Government guarantees (and the provisions made for losses on guarantees) are normally recorded off-balance sheet in ESA 95 unless there is a high certainty of a guarantee to be called. Additionally, there are other support measures which count as government contingent liabilities in national accounts, e.g. government securities lent or swapped without cash collateral in temporary liquidity schemes. Guarantees on retail bank deposits are another form of contingent liability. The direct costs are recorded in government debt (e.g. capital injections for banks for which the government had to borrow in the market) and recovering these costs will depend on the future value of the acquired bank assets.

Table 9 shows the cumulative amount of contingent liabilities as a result of the stabilisation operations carried out in the financial sector during the period 2008-10. There are two relevant figures, namely a ceiling and a willingness of government to grant guarantees of up to $13.1 \%$ of GDP for the euro area on average in support of financial institutions. In practice, guarantees issued by euro area governments amount to roughly half of the ceiling, i.e. $6.5 \%$ of GDP. Most notably, the Irish government has underwritten particularly vast guarantees of some $125 \%$ of GDP, including the blanket guarantee under the Credit Institutions Financial Support Scheme ${ }^{23}$ (CIFS) and the subsequent eligible liability guarantees. In the case of Greece, the government granted guarantees amounting to $25.1 \%$ of GDP in order to maintain the stability of the Greek banking system. For Cyprus, the guarantees amounting to $17.2 \%$ of GDP refer to asset swaps and lending. Another exceptional case is Belgium, where guarantees worth roughly $15.8 \%$ of GDP mainly cover an interbank guarantee (to the Belgian part of Dexia) and asset protection schemes.

The fiscal risks stemming from the $6.5 \%$ of GDP committed to off-balance-sheet liabilities depend on the probability of the guarantees

23 The CIFS scheme followed on from the announcement by the Irish government on 30 September 2008 that it would guarantee the covered liabilities of Bank of Ireland, AIB, Anglo Irish Bank, EBS Building Society, Irish Nationwide Building Society, and Irish Life and Permanent. This initially amounted to twice the size of the economy (by 2010, the contingent liabilities had been reduced to the equivalent of the size of the economy). 


\begin{tabular}{|c|c|c|c|c|c|c|c|c|}
\hline \multicolumn{9}{|c|}{ (pencentage of GDP) } \\
\hline & \multicolumn{6}{|c|}{ Measures impacting on government debt (2008-10) } & \multicolumn{2}{|c|}{$\begin{array}{l}\text { Measures impacting on } \\
\text { government contingent } \\
\text { liabilities (2008-10) }\end{array}$} \\
\hline & $\begin{array}{l}\text { Capital ir } \\
\text { Acquisition } \\
\text { of shares }\end{array}$ & $\begin{array}{l}\text { ions } \\
\text { Loans }\end{array}$ & $\begin{array}{r}\text { Asset } \\
\text { purchase }\end{array}$ & $\begin{array}{r}\text { Other } \\
\text { measures }\end{array}$ & $\begin{array}{r}\text { Total impact } \\
\text { on government } \\
\text { debt }\end{array}$ & $\begin{array}{r}o / w \\
\text { redemptions }\end{array}$ & $\begin{array}{r}\text { Total } \\
\text { contingent } \\
\text { liabilities }\end{array}$ & Ceiling \\
\hline Belgium & 5.7 & 0.0 & 0.0 & 0.1 & 5.8 & 2.0 & 15.8 & 28.0 \\
\hline Germany & 1.9 & 0.0 & 11.1 & 0.5 & 13.5 & 0.0 & 2.8 & 7.1 \\
\hline Estonia & 0.0 & 0.0 & 0.0 & 0.0 & 0.0 & 0.0 & 0.0 & 0.0 \\
\hline Ireland & 7.0 & 0.0 & 0.0 & 16.2 & 23.2 & 0.0 & 125.2 & 125.2 \\
\hline Greece & 1.6 & 0.0 & 0.0 & 0.7 & 2.3 & 0.0 & 25.1 & 27.4 \\
\hline Spain & 0.0 & 0.0 & 2.4 & 0.0 & 2.4 & 0.2 & 5.6 & 5.8 \\
\hline France & 0.2 & 0.0 & 0.0 & 0.0 & 0.2 & 0.4 & 4.7 & 23.6 \\
\hline Italy & 0.3 & 0.0 & 0.0 & 0.0 & 0.3 & 0.0 & 0.0 & 0.0 \\
\hline Cyprus & 0.0 & 0.0 & 0.0 & 0.0 & 0.0 & 0.0 & 17.2 & 17.2 \\
\hline Luxembourg & 6.1 & 0.0 & 0.0 & 0.0 & 6.1 & 0.2 & 3.2 & 3.2 \\
\hline Malta & 0.0 & 0.0 & 0.0 & 0.0 & 0.0 & 0.0 & 0.0 & 0.0 \\
\hline Netherlands & 5.8 & 0.8 & 2.4 & 0.0 & 9.0 & 9.7 & 6.8 & 6.8 \\
\hline Austria & 2.1 & 0.0 & 0.0 & 0.4 & 2.6 & 0.0 & 7.8 & 17.6 \\
\hline Portugal & 1.2 & 0.0 & 2.2 & 0.3 & 3.6 & 0.0 & 3.1 & 11.7 \\
\hline Slovenia & 0.0 & 0.0 & 0.4 & 3.5 & 4.0 & 0.0 & 6.1 & 33.3 \\
\hline Slovakia & 0.0 & 0.0 & 0.0 & 0.0 & 0.0 & 0.0 & 0.0 & 0.0 \\
\hline Finland & 0.0 & 0.0 & 0.0 & 0.0 & 0.0 & 0.0 & 0.0 & 0.0 \\
\hline Euro area & 1.5 & 0.1 & 3.5 & 0.5 & 5.5 & 0.8 & 6.5 & 13.1 \\
\hline
\end{tabular}

being called. The probability of materialisation of these guarantees depends on the default risk of the financial institutions to which the guarantees are attached (see, for example, Attinasi, 2010). In this event ${ }^{24}$, the amount called is recorded in the ESA 95 accounting system as a capital transfer, thus directly impacting on government expenditure by the same amount. The subsequent impact on the government deficit and also on (explicit) government debt depends on how this capital transfer is financed, i.e. via taxes (impacting on the government deficit through revenue and expenditure) or via government borrowing (impacting on the deficit solely through expenditure and government debt via the financial instrument selected). Alternatively, the government can sell part of its assets, thereby limiting the impact on the government deficit to the capital expenditure incurred. In the euro area, most of the liabilities during the financial crisis became explicit in government accounts on a de facto basis due to the purchase of impaired assets $3.5 \%$ of GDP, during the period 2008-10).
In response to the financial crisis, governments across Europe also embarked on support measures other than public guarantees. In order to restore confidence in the banking sector, governments provided support in the form of recapitalisations (through purchases of new equity) and by providing liquidity (purchase of impaired assets, issuing of loans, asset exchanges/swaps). To ensure that government deficit and debt statistics are compiled consistently and homogenously across the EU Member States, Eurostat published methodological guidance ${ }^{25}$ on how to record the operations carried out in response to the financial crisis, on the basis of ESA 95. In the Irish case, the support measures were related to the capital injections for Allied

24 When the debtor (bank) is unable to meet its liability this will usually result in the government either making a payment to the original creditors or assuming a debt.

25 The 2009 Eurostat Decision on the statistical recording of public interventions to support financial institutions and financial markets during the financial crisis, accessible via the following link: $<$ http://epp.eurostat.ec.europa.eu/portal/page/portal/government finance_statistics/methodology/decisions_for_GFS $>$. 
Irish Bank, Bank of Ireland and Anglo Irish Bank as well as the transfer of loans to the National Assets Management Agency (NAMA). These operations substantially impacted on explicit government debt, with a cumulative increase of $23.2 \%$ for $2008-10$ (notably in 2010$)^{26}$ and also on the government deficit. In Germany, the crystallisation of support to the banking sector has also resulted in a considerable increase in (explicit) government debt (13.5\% of GDP). This stems from capital injections to Commerzbank and various Landesbanken (2008-09) and a transfer of non-strategic assets and liabilities from WestLB AG to Erste Abwicklungsanstalt (EAA) as well as interventions related to HRE bad banks $^{27}$ during 2010. In the Netherlands, the measures to support Fortis, ABN AMRO and ING resulted in a remarkable cumulative increase in (explicit) government debt of around $9.0 \%$ of GDP for the period 2008-10. In Belgium, the cumulative increase in (explicit) government debt of around $5.8 \%$ of GDP, also for the period 2008-10, was due to capital injections in Fortis, Dexia and KBC.

Since the governments had already recovered around $0.8 \%$ of GDP (redemptions) from the financial sector, the net direct impact on government debt through to end-2010 amounted to $5.5 \%$ of GDP in the euro area. Excluding redemptions, the total direct impact of financial-sector operations on government debt was $6.3 \%$ of GDP for the euro area. In the case of the Netherlands the redemptions were particularly sizeable (almost $9.7 \%$ of GDP) due to repayments of loans in 2009; in other words, the Dutch government already recovered more than half of the amount of the total direct impact of financial-sector operations (18.7\% of GDP) over the period 2008-10.

Moreover, since May 2010 there are additional contingent liabilities derived from the bilateral and multilateral financial support arrangements for the euro area countries in distress, subject to strict policy conditionality. Firstly, the joint EU/ IMF support package for Greece included bilateral loans from euro area countries that will impact on the government debt of the supporting euro area countries and the beneficiary country. However, as aggregate government debt is consolidated for such intergovernmental lending, the total impact on euro area government debt will be almost $€ 78$ billion (around $0.9 \%$ of GDP) over the period 2010-13 (see Annex II). Second, the European Financial Stability Fund (EFSF) established in June 2010 by the EU Council as a limited liability company under Luxembourg law aims to safeguard financial stability within the euro area as a whole. The main purpose is to collect funds and to provide loans in conjunction with the IMF to cover the financing needs of the euro area countries in difficulty. This implies that euro area countries have provided guarantees for EFSF issuance up to a total ceiling of $€ 779.6$ billion (around 8.5\% of euro area GDP) on a pro rata basis over the period 2010-13 (see Table 10, second column) in order to constitute the EFSF lending capacity of $€ 440$ bn. This lending capacity is already being used to support Ireland and Portugal (see Annex II) and it will also be used in future for Greece. ${ }^{28}$ The granting of guarantees as such has no impact on government accounts as the guarantees will be recorded as contingent liabilities. However, (explicit) government debt will increase if a euro area country in difficulty requests a loan from the EFSF. In practice, activation of the EFSF in the form of financial support to Ireland ${ }^{29}$ in November 2010 and to Portugal $^{30}$ in May 2011 already indicates that government debt (and assets) will increase

26 After the restructuring of Anglo Irish Bank and Irish Nationwide Building Society, the debt-to-GDP ratio in Ireland totalled 96.2\% of GDP in 2010 (four times higher than in 2007).

27 Bad banks are also referred to as "financial entities managing problematic assets" (FEMPA).

28 At the time of writing, the approval of the disbursements to Greece under the EFSF was still being finalised.

29 The total bailout for Ireland amounts to $€ 85$ billion (around 54\% of Ireland's 2010 GDP), of which $€ 17.5$ billion will come from the National Pension Reserve Fund (NPRF) and other domestic cash resources; $€ 22.5$ billion from the IMF; $€ 22.5$ billion from the European Financial Stability Mechanism (EFSM) with no direct impact on government debt as this support is operationalised via the EU budget; $€ 22.5$ billion jointly from the EFSF ( $€ 17.7$ bn) and the bilateral loans from Denmark, Sweden and the UK (€4.8 bn)

30 The total bailout for Portugal amounts to $€ 78$ billion (around $46 \%$ of Portugal's 2011 GDP), of which $€ 26$ billion are granted by the IMF; $€ 26$ billion from the EFSM and the remaining $€ 26$ billion from the EFSF. 


\begin{tabular}{|c|c|c|c|c|c|}
\hline \multicolumn{6}{|l|}{ (EUR billion) } \\
\hline & \multicolumn{2}{|c|}{ EFSF (2010-13) } & \multicolumn{3}{|c|}{ ESM (2013-17) } \\
\hline & $\begin{array}{r}\text { Effective lending } \\
\text { capacity }\end{array}$ & $\begin{array}{r}\text { Maximum (over) } \\
\text { guarantees }\end{array}$ & $\begin{array}{r}\text { Effective lending } \\
\text { capacity }\end{array}$ & Subcribed capital & Paid-in capital \\
\hline Belgium & 15.3 & 27.0 & 17.4 & 24.3 & 2.8 \\
\hline Germany/KdW & 119.4 & 211.0 & 135.7 & 190.0 & 21.7 \\
\hline Estonia & . & 2.0 & 0.9 & 1.3 & 0.1 \\
\hline Ireland & 7.0 & 12.4 & 8.0 & 11.1 & 1.3 \\
\hline Greece & 12.4 & 21.9 & 14.1 & 19.7 & 2.3 \\
\hline Spain & 52.4 & 92.5 & 59.5 & 83.3 & 9.5 \\
\hline France & 89.7 & 158.5 & 101.9 & 142.7 & 16.3 \\
\hline Italy & 78.8 & 139.3 & 89.6 & 125.4 & 14.3 \\
\hline Cyprus & 0.9 & 1.5 & 1.0 & 1.4 & 0.2 \\
\hline Luxembourg & 1.1 & 1.9 & 1.3 & 1.7 & 0.2 \\
\hline Malta & 0.4 & 0.7 & 0.4 & 0.5 & 0.1 \\
\hline Netherlands & 25.1 & 44.4 & 28.6 & 40.0 & 4.6 \\
\hline Austria & 12.2 & 21.6 & 13.9 & 19.5 & 2.2 \\
\hline Portugal & 11.0 & 19.5 & 12.5 & 17.6 & 2.0 \\
\hline Slovenia & 2.1 & 3.7 & 2.1 & 3.0 & 0.3 \\
\hline Slovakia & 4.3 & 7.7 & 4.1 & 5.8 & 0.7 \\
\hline Finland & 7.9 & 14.0 & 9.0 & 12.6 & 1.4 \\
\hline Euro area & 440.0 & 779.6 & 500.0 & 700.0 & 80.0 \\
\hline
\end{tabular}

Source: ESCB

Notes: 1) The bilateral loans to Greece as approved in the first EU/IMF rescue package (2010). 2) The commitments under the EFSF as amended in the European Council conclusions of 23/24 June 2011. 3) The commitments under the ESM in the form of paid-in capital in relation to the total subscribed capital of $€ 700$ billion as specified in the European Council conclusions of 23/24 June 2011.

during the period $2011-13^{31}$ in the supporting and beneficiary euro area countries, as will "consolidated" euro area government debt. Finally, the tasks of the EFSF and the EFSM will be taken over by the European Stability Mechanism (ESM) after June 2013 as a permanent crisis resolution mechanism (see ECB (2011c) for further details). The lending capacity of the ESM will be $€ 500$ billion and its funding will also be guaranteed by the euro area countries as illustrated in Table 10. However, a new feature compared to the EFSF is that the ESM will incorporate a $€ 80$ billion paid-in capital, implying a capability to withstand own risks. Another important relevant aspect is that, unlike loans provided by the EFSF, future loans granted by the ESM will not impact on the government accounts of the supporting euro area countries and will therefore not increase their (explicit) government debt. ${ }^{32}$

The fiscal risks ${ }^{33}$ derived from contingent liabilities tend to be more short-term and have solvency implications for the viability of government debt levels. Together with the publication of the amounts of contingent liabilities, the key point is transparent reporting of fiscal risk statements, which would ideally include subsequent probabilities and the timing of materialisation (Everaert et al., 2009). This information would constitute a valuable input for the debt management strategy.

31 According to the Eurostat Decision on the statistical recording of operations undertaken by the European Financial Stability Facility (27 January 2011), the loans provided via the EFSF will increase the EDP debt of either the supporting or guarantor countries (in proportion to their respective shares in the guarantees provided to the EFSF) or the beneficiary euro area countries by the amount they are considered to have borrowed from the EFSF. In substance, this implies that they are recorded in the same way as the direct bilateral loans from one member country to another, as in the case of the bilateral loans to Greece. Moreover, the government deficit/surplus of the supporting euro area countries will be impacted positively through the net revenue streams (such as interest and service fees). Hence, the EFSF acts as the treasurer for the euro area countries ensuring that the borrowing conditions are the same. In parallel, the loans granted by the EFSF are considered as loans directly granted by these euro area countries, thus also raising their financial assets.

32 According to Eurostat's preliminary view on how to record the future European Stability Mechanism (7 April 2011), the ESM loans should be treated as a direct loan from an international organisation, such as the IMF, to the euro area country in question.

33 The fiscal risk in this context would result from the difference between the actual and the expected fiscal outcomes in terms of government debt, which may be caused for example by economic shocks, natural disasters or calls on government guarantees. 
Table II Accrued-to-date pension entitlements, as compiled by the OECD, the IMF, DESTATIS, INSEE and the Eurostat/ECB Task Force on Pensions, for the euro area and selected euro area countries (as percentage GDP)

\begin{tabular}{|c|c|c|c|c|c|c|}
\hline Source & $\mathrm{OECD}^{1)}$ & IMF $^{1)}$ & DESTATIS ${ }^{2)}$ & INSEE $^{3)}$ & \multicolumn{2}{|c|}{$\begin{array}{c}\text { Eurostat/ECB Task Force } \\
\text { on Pensions }\end{array}$} \\
\hline Method & $\begin{array}{l}\text { Implicit pension } \\
\text { debt }(\mathrm{ABO})\end{array}$ & $\begin{array}{l}\text { Implicit pension } \\
\text { debt }(\mathrm{PBO})\end{array}$ & $\begin{array}{l}\text { Accrued-to-date } \\
\text { liabilities (PBO) }\end{array}$ & $\begin{array}{l}\text { Accrued-to-date } \\
\text { liabilities (PBO) }\end{array}$ & \multicolumn{2}{|c|}{ Accrued-to-date liabilities (PBO) } \\
\hline Coverage & \multicolumn{2}{|c|}{ Pension liabilities in the public sector } & \multicolumn{2}{|c|}{ Social security } & Social security & $\begin{array}{l}\text { Defined-benefit } \\
\text { schemes }\end{array}$ \\
\hline End-year & 1990 & 1995 & 2005 & 2003 & 2007 & 2007 \\
\hline Germany & $157^{4)}$ & $221^{4)}$ & 230 & - & 275 & 47 \\
\hline France & 216 & 265 & - & 259 & 292 & 60 \\
\hline Italy & 242 & 357 & - & - & $322^{5)}$ & $1^{5)}$ \\
\hline Euro area & - & - & - & - & 278 & 52 \\
\hline
\end{tabular}

Sources: 1) OECD and IMF studies, op. cit. by: Holzmann et al. (2001).

2) Braakmann et al. (2007, pp. 1167-1179).

3) Blanchet and Le Minez (2008).

4) Data refer to West Germany.

5) End-2006.

It should be noted that the capital injections into banks also mean that governments have acquired assets from the banks (in the form of equity or loans) that can be sold in the future to redeem debt. Likewise, the liabilities in the countries in distress related to the bilateral loans or to the EFSF imply actual assets on the balance sheet of the supporting euro area countries.

Finally, there may be other reasons for contingent liabilities, such as natural disasters: Liz and Nickel (2009) for example discuss the implications of extreme weather events for fiscal policy and publicly provided disaster insurance.

\subsection{IMPLICIT ASSETS AND LIABILITIES}

The aim of this sub-section is firstly to illustrate the problem of measuring implicit liabilities and showing the existing figures for the euro area and euro area countries, and secondly to introduce the concept of implicit assets.

\section{IMPLICIT LIABILITIES}

An existing approach from national accounts used to measure implicit liabilities refers to the net present value arising from the current government-managed pension schemes ${ }^{34}$, i.e. accrued-to-date liabilities. Table 11 shows an overview of the different studies that calculate these implicit liabilities. In the euro area, this would represent around $330 \%$ of GDP (end-2007) (see ECB 2010 and Mink et al. 2008). From this amount, government-managed defined-benefit schemes represent around $50 \%$ of GDP while social security pension schemes account for roughly $280 \%$ of GDP. Similar magnitudes apply to the selected euro area countries. While the compilation of the accrued-to-date pension liabilities precludes an assessment of the sustainability of public finances (where future contributions should also be discounted), the main message from these estimates is that if all pension-related (implicit) liabilities are taken into account, government obligations in the euro area are more than four times higher than current ESA or EDP (explicit) debt. Nevertheless, these existing obligations will only be paid out over the decades ahead.

A typical example of implicit liabilities refers to the increasing potential costs for governments from ageing populations, which can be calculated from several perspectives. In the euro area context, the 2009 Ageing Report ${ }^{35}$ calculates the projected growth in the ageing-

34 The reason why some liabilities related to pension schemes are classified as implicit is the fact that they are not recorded in government statistics. In particular, the liabilities of the unfunded benefit-defined schemes depend on the future development of many variables (e.g. macro variables affecting the outcome of indexation rules, time-varying characteristics of contributors to the pension system, such as their salaries/contributions, etc.)

35 European Commission and the Economic Policy Committee (2009). 
related government expenditure-to-GDP ratio, which is projected to rise by 5.2 percentage points (of which $2.8 \%$ of GDP refers to public pensions, $1.4 \%$ to public health care, $1.4 \%$ to long-term care, $-0.2 \%$ to unemployment benefits and $-0.2 \%$ to education) over the period 2007 60 , assuming that policies remain unchanged and based on pre-crisis potential growth projections (see Table 12). The main message from these projections is that future primary budget deficits, and therefore government debtto-GDP ratios, will rise if no reforms are undertaken - particularly as regards pension systems, thus raising risks to fiscal sustainability. Similar results are obtained by Velculescu (2010) who, using forward-looking fiscal measures of intertemporal net worth derived both directly from the European Commission's Ageing Working Group's long-term indicators and using a comprehensive public-sector balance sheet approach, claims that the intertemporal net worth of EU27 is deeply negative, even in excess of its GDP level, and is projected to deteriorate further over time. This suggests that Europe's current policies need to be significantly strengthened to bring future liabilities into line with the EU governments' capacity to generate assets. Thus, parametric or systemic reforms of pension schemes are on the agenda in most euro area countries. The issue has been addressed under the preventive arm of the SGP, as the costs of ageing are acknowledged in the formula for calculating the countries' medium-term budgetary objectives (MTOs), whereby stronger projected increases in ageing-related government expenditure-to-GDP ratios result in more ambitious MTOs. ${ }^{36}$

Nonetheless, the situation substantially differs between the countries according to differences in the pace and timing of ageing, specific features of national pension schemes and public health care, and a country's relative position in the pension and healthcare reform process. Additionally, the ageing-related government expenditure-to-GDP ratio could accelerate depending on different assumptions about the long-term impact of the financial and economic crisis on fiscal positions. ${ }^{37}$

\begin{tabular}{|c|c|c|c|}
\hline \multicolumn{4}{|c|}{$\begin{array}{l}\text { Table } 12 \text { Increases of } \\
\text { government expenditu } \\
\text { the period } 2007-60\end{array}$} \\
\hline \multicolumn{4}{|c|}{ (as percentage points of GDP) } \\
\hline GDP & $2007-60$ & GDP & $2007-60$ \\
\hline Belgium & 6.9 & Luxembourg & 18.0 \\
\hline Germany & 4.8 & Malta & 10.2 \\
\hline Estonia & 0.4 & Netherlands & 9.4 \\
\hline Ireland & 8.9 & Austria & 3.1 \\
\hline Greece & 15.9 & Portugal & 3.4 \\
\hline Spain & 9.0 & Slovenia & 12.8 \\
\hline France & 2.7 & Slovakia & 5.2 \\
\hline Italy & 1.6 & Finland & 6.3 \\
\hline Cyprus & 10.8 & Euro area & 5.2 \\
\hline \multicolumn{4}{|c|}{$\begin{array}{l}\text { Sources: European Commission and Economic Policy Committee } \\
\text { ( } 2009) \text {. } \\
\text { Note: For some countries (e.g. Greece, Spain) pension reforms } \\
\text { have recently been implemented which are not reflected in } \\
\text { the table. }\end{array}$} \\
\hline
\end{tabular}

In terms of implicit liabilities, the risks of materialisation are in the medium- and long-term and therefore relate more to the sustainability of public finances. In any case, given the magnitude of the expected growth in government expenditure due to ageing populations and, in particular, the potentially high levels of pension obligations, the governments need to find an intergenerational balance between securing appropriate social insurance in the future while keeping the social security burden for members of the labour force within reasonable limits.

\section{IMPLICIT ASSETS}

Buiter (1983) defined implicit government assets as the present value of a future tax programme, including social security contributions and tariff revenues. Similarly Auerbach (2008, p.13) argued that: "Just as one may identify implicit liabilities in spending programmes that have the

36 The Code of Conduct (endorsed by the ECOFIN Council on 7 September 2010) specifies that the country-specific MTOs should take into account three components: i) the debt-stabilising balance for a debt ratio equal to the $(60 \%$ of GDP) reference value (dependent on long-term potential growth), implying room for budgetary manoeuvre for member countries with relatively low debt; ii) a supplementary debt-reduction effort for member countries with a debt ratio in excess of the (60\% of GDP) reference value, implying rapid progress towards it; and iii) fraction of the adjustment needed to cover the present value of the future increase in age-related government expenditure. This implies a partial frontloading of the budgetary cost of ageing irrespective of the current level of debt.

37 See Box 7 in ECB (2009). 
same attributes as explicit national debt, there are differences among tax systems that amount to the establishment of implicit assets and liabilities. Ignoring these differences makes no more sense than ignoring explicit government liabilities." Implicit assets may be regarded as a group of off-balance-sheet items that can possibly turn into explicit government assets in the future and which may help to restore longterm fiscal sustainability, in particular when implicit liabilities (e.g. those implicit within the unfunded PAYG pension pillar) start to materialise. One of the reasons why implicit assets are not recorded is linked to the fact that they relate to the future and are difficult to quantify and cost, especially in the current circumstances. For example, an implicit asset can be seen in a future government's tax revenue opportunities. Imposing new taxes or broadening the existing tax base is one option for possible consideration as an implicit government asset. How much a government can increase taxation in the future - tax space - is dependent on several parameters: (i) the lower the current tax burden, the greater the opportunity to increase it in the future. Hence, countries with a lower tax burden today (e.g. Slovakia, Ireland, Spain, Greece) should have higher implicit assets related to possible future tax revenues (see Chart 5) while countries with an already high tax burden may have no further leeway for increasing taxation; (ii) countries with a more efficient tax administration (i.e. with a higher probability of a tax audit and issuance of a penalty for tax underpayments) are able to better enforce increases in taxes, hence their governments have a higher implicit asset related to those revenues; (iii) the preference of the public to pay additional taxes is higher when government provides welltargeted services and spends money efficiently. The quality of government expenditure plays an important role in determining how much the public is willing to pay to finance such expenditure. Therefore, lowering the current tax burden and creating a buffer to increase the potential leeway for possible future increases when some of the existing implicit liabilities will start to materialise, and also improving tax administration and the quality of public expenditure, may be regarded as measures for increasing implicit government assets.

Other implicit assets may include, inter alia, future dividend revenues from publicly owned profitable companies or claims from future court decisions or sanctions which a government can impose on entities that misbehave. The sanctions could be, for example, linked to the pricing of externalities, such as environmental pollution or damage. Governments which introduce the possibility to sanction or broaden the sanction for certain types of misbehaviour under their laws increase their possible future revenues and thus also their implicit assets.

Finally, since the bulk of future implicit liabilities relates to the unfunded pension system schemes and the related ageing populations, governments may build up implicit assets to finance these liabilities in the future in the form of additional social contributions. They may include, for example, government measures

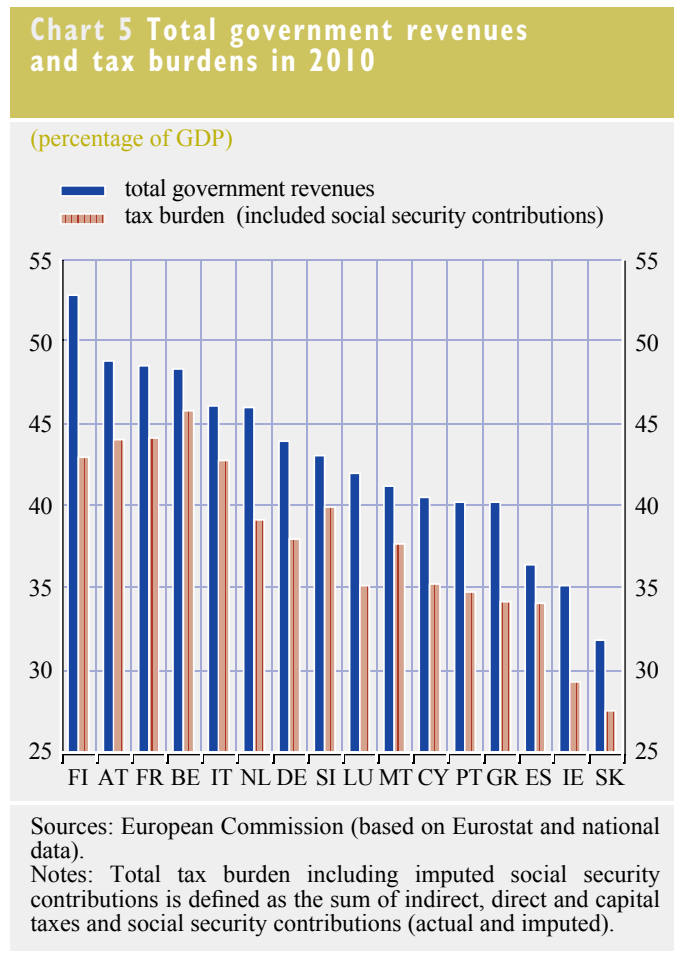


that: (i) improve the efficiency of the medical system and other ageing-related costs in the future, or (ii) stabilise the old-age dependency ratio to improve the financial stability of PAYG systems, for example by activating the inactive population outside the labour force. Steps related to improvements in the labour market, especially the employability and retraining of people closer to retirement age in order to keep those same people in work, creating conditions for a migration inflow or increases in the labour force, may be seen from this perspective as creating implicit government assets. In addition, the possibility of taxing previously untaxed pension benefits could be another example of an implicit government asset. 
central banks to tolerate higher inflation with a

The composition of government debt in terms of maturity, indexation, currency and investor base influences both a government's costs and the risks related to the rollover of outstanding government debt. A government, or its appointed agency, typically known as the debt management office, tries to minimise the costs in view of the risks related to the issuance of government debt. In this respect, it is guided by the debt management strategy, which explicitly sets out the government's medium-term objectives for managing its debt. In addition, the focus may be on certain targets, such as the development of the sovereign bond market (e.g. by increasing the liquidity of certain market segments, re-opening government benchmark bonds, issuing government debt in maturities which match the demands of investors, or were absent and so complicated the construction of the yield curve) or on avoiding any accumulation of issuance activity by more issuers within the same period.

There are several macroeconomic reasons for attaching importance to the composition of government debt. First, particularly in developed economies, the government bond yield curve serves as a benchmark for pricing private sector bonds. The maturity composition of government debt affects the yield curve and hence the financing conditions of the private sector, with possible effects on overall economic activity. Higher government borrowing under certain conditions (see, for example, Buiter et al., 1985) crowds out possible private sector borrowings that are crucial for long-term economic growth. Second, with a high share of short-term debt the government may be vulnerable to increases in monetary policy rates. If a government has to take fiscal measures to counteract the effect of higher interest expenditure on the overall budget balance, this may have a negative impact on economic activity. The government may then have an incentive to put pressure on the central bank to maintain low policy rates. Third, Wolswijk and de Haan (2005) claim that issuing inflation-indexed bonds may reduce the incentives for governments to put pressure on view to reducing the real value of government debt, although they argue that a high degree of central bank independence is a better safeguard against this. Fourth, domestic currency denomination protects euro area governments against exchange rate movement risks related to currency mismatches between a government's interest expenditure and tax revenue. Finally, the share of the domestic versus the foreign investor base could have consequences in situations of sudden foreign capital stops or bigger exchange rate movements. The domestic investor base, given its access to a wider range of information on domestic developments and policies, may be relatively smaller depending on rating agencies' assessments and less prone to a herd mentality compared to the foreign investor base.

Chart 6 shows the composition of government debt in the euro area broken down by type of financing instrument, the level of government issuing the instrument, residual maturity ${ }^{38}$ and debt holders/creditors. ${ }^{39}$ Long-tem securities, i.e. securities with initial maturity of over one year, represented $70 \%$ of government debt in the euro area in 2010, while short-term securities accounted for $9 \%$, and loans from financial institutions, which are typically used at the municipal level, corresponded to $18 \%$ of EDP debt. Around $83 \%$ of EDP debt comprised debt issued by central government, while the remaining $17 \%$ was issued by local (municipal) government, state governments or social security funds.

The non-residents in a given euro area country, which include non-residents both inside and outside the euro area, held some $52 \%$ of EDP debt, while residents held the remaining $48 \%$, out of which $38 \%$ of the total was held by monetary and financial institutions, under $2 \%$

38 The residual maturity is the time from the reference date until the contractual redemption date of an instrument

39 Euro area government debt held by residents refers to holders resident in the country whose government has issued the debt. They are also referred to as "domestic creditors". Euro area debt held by non-residents includes residents of euro area countries other than the country whose government has issued the debt. 


\section{Chart 6 Euro area government debt structure in 2010}

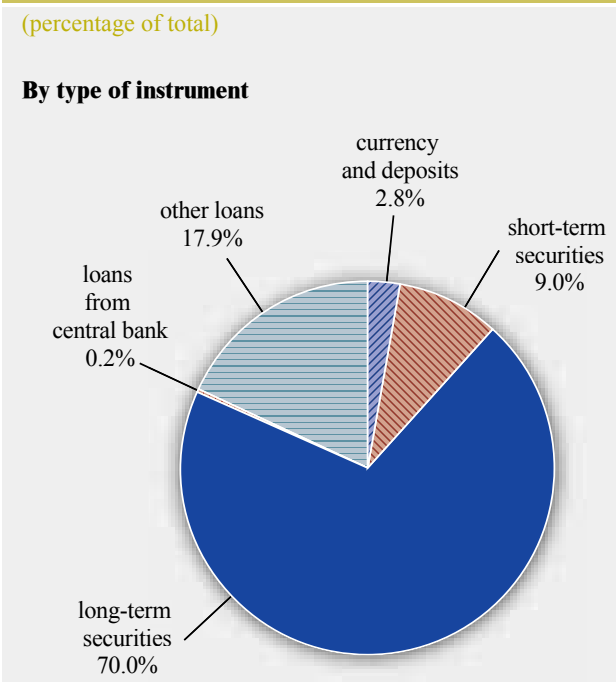

By debt holder

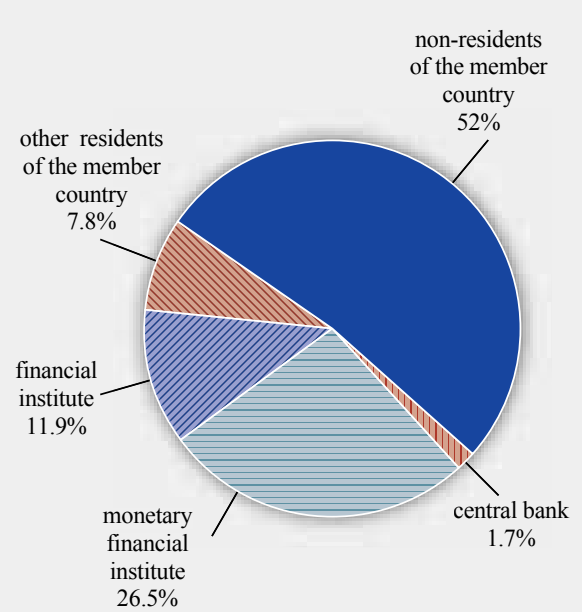

By sector contribution

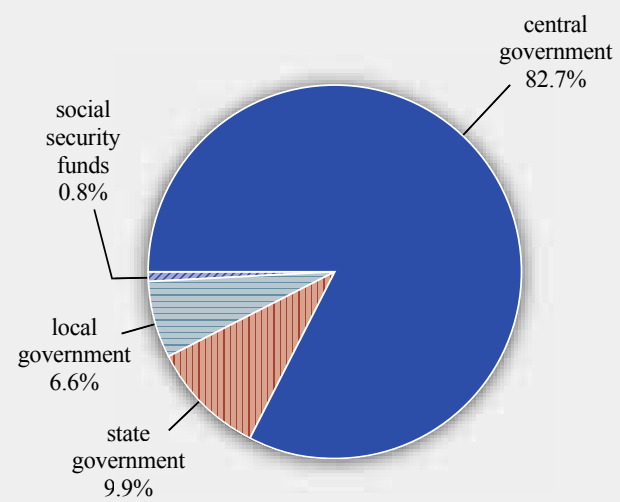

By residual maturity

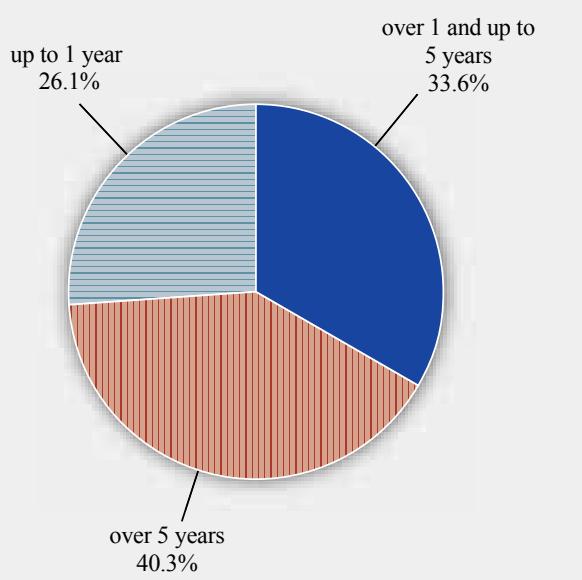

Source: ESCB.

Nource: ESCB.
Note: Data refer to EDP debt. Gross general government debt at nominal value and consolidated between sub-sectors of government.

by the central bank and some $8 \%$ of the total by other residents, e.g. individuals and non-financial corporations. Regarding the currency decomposition, roughly $99 \%$ of the euro area government debt securities are denominated in euro; this makes the euro area governments virtually insensitive to exchange rate movements. In addition, the denomination of government debt in the domestic currency, which is also the currency in which the euro area governments collect taxes, reduces problems with possible currency mismatches.
Under normal circumstances, governments tend to prioritise reducing the debt-servicing costs given a certain level of risk. In special circumstances, especially when financial markets do not work smoothly, more attention needs to be paid to minimising the refinancing risk. In particular, in an environment of very low short-term interest rates issuance activity may shift towards short-term instruments in order to minimise the government's costs (interest payments). However, as this would increase the refinancing risk, the government could face a 
situation in which a huge amount of outstanding government debt needs to be rolled over in a short period of time and market conditions deteriorate in such a way that investors either demand substantially higher yields on their investments or are unwilling to buy certain government bills or bonds at all.

The composition of government debt is determined by the interactions between the government as issuer and investors who buy the debt instruments on offer. Both the government and investors have their own preferences which may not always fully match. The government needs to finance its deficit and roll over the maturing debt. The investors may have heterogeneous preferences, depending on their investment strategy. For example, long-term investors such as pension funds may demand fairly long-term maturities which would match the maturity profile of their liabilities, while commercial banks or non-financial corporations may prefer short-term instruments for their liquidity management.

Past memories also play an important role. For example, investors in countries with a track record of relatively high inflation or frequent changes in market conditions may demand instruments with variable interest rates which would compensate them if economic or financial market conditions were to change from the time of issuance. In this respect, inflationindexed bonds may be considered as another way in which institutional investors can match their inflation-sensitive liabilities or diversify long-term investment portfolios. The sovereign inflation-linked bond markets in the euro area developed around $2003^{40}$ (see Garcia and van Rixtel, 2007) and currently centre on three countries, namely France, Germany and Italy. In practice, however, as illustrated below in Chart 7, the ratio of inflation-indexed bonds in the euro area has been falling since 2008, to levels of around $5 \%$ of total government debt issuance in 2009 and 2010. The intensification of financial turbulence was a major obstacle for the inflation-linked bond market in 2009-10. The change in macroeconomic conditions, in particular the sharp declines in oil prices, lowered worldwide demand for inflation protection in that period. Moreover, the increasingly tough liquidity conditions in financial markets triggered a major sell-off of inflation-linked bonds, whose prices, in the light

40 Only France began issuing inflation-linked bonds since 1998.
Greece and Italy started in 2003 and Germany in 2006. Slovenia issued inflation-indexed bonds only in 2000-02 .

\section{Chart 7 Inflation-linked bonds in the euro area}

(percentage; annual data)

a) Ratio of inflation-indexed government debt to total nominal government debt in the euro area
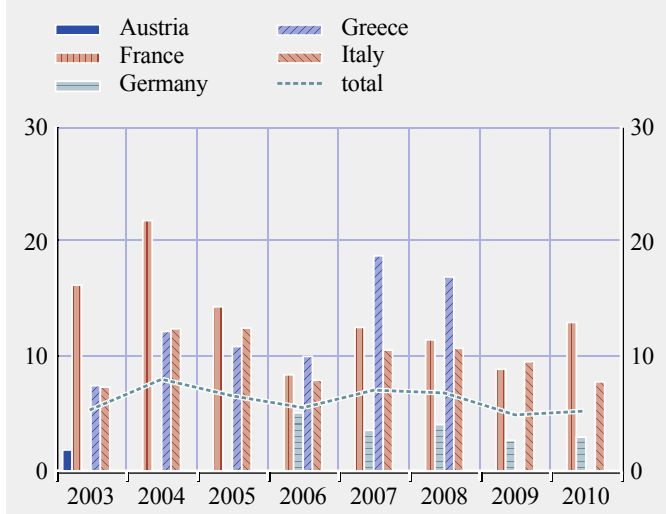

ource: Dealogic database. b) Issuance of inflation-linked government bonds in the euro area

$$
\begin{array}{lll}
\text { Austria } & \text { wos } & \text { Greece } \\
\text { France } & \text { axw Italy } \\
\text { Germany } & & \text { Slovenia }
\end{array}
$$

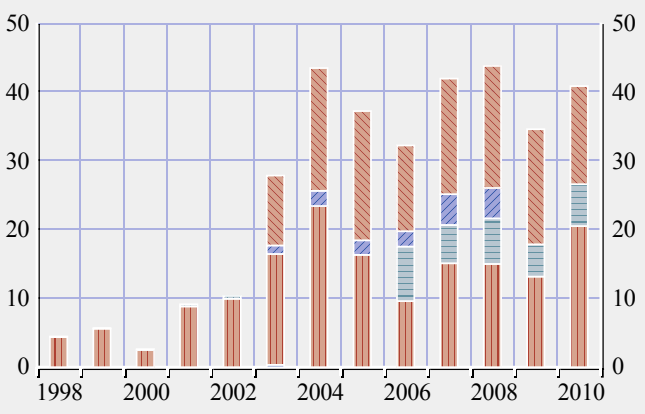




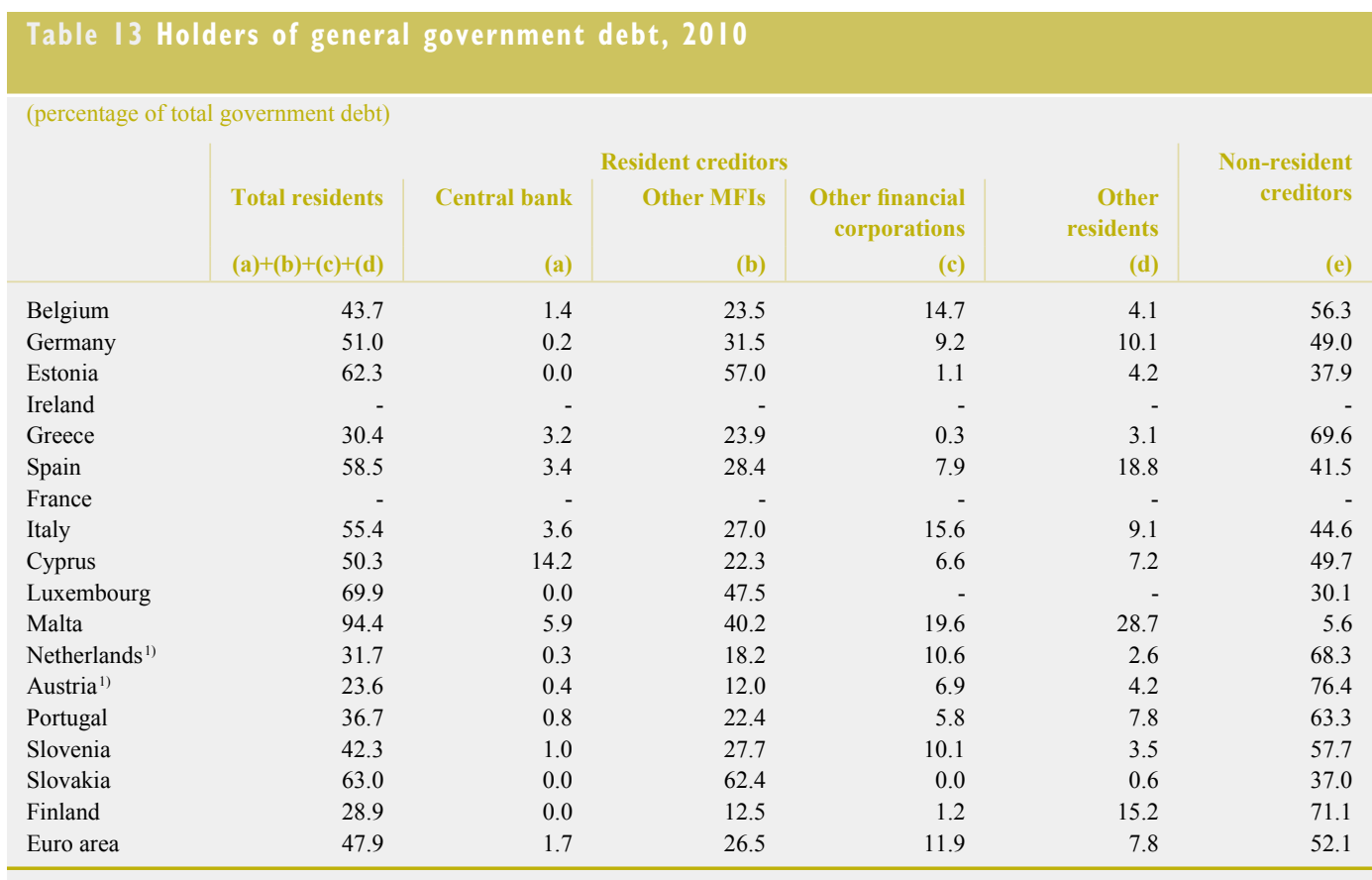

Source: ESCB.
Notes: Data refer to EDP debt. Gross general government debt at nominal value and consolidated between sub-sectors of government. Intergovernmental lending in the context of the financial crisis is consolidated.

1) Data refer to 2009 .

of low demand, plummeted not only in the euro area but also in global markets. Faced with such adverse demand conditions, primary issuance was somewhat limited in 2009 and 2010.

Tables 13, 14 and 15 show the variations between the euro area countries with regard to debt holders, debt currency denomination and residual maturity.

As seen in Table 13, non-residents are the major government debt holders in Belgium, Greece, the Netherlands, Austria, Portugal, Slovenia and Finland, while residents are the dominant holders in Germany, Estonia, Spain, Italy, Cyprus, Malta and Slovakia. Monetary and financial institutions (MFIs) (i.e. credit institutions such as banks, excluding central banks, and money market funds) together with other financial corporations (i.e. insurance corporations, pension funds, financial auxiliaries, mutual funds, securities and derivatives dealers and financial corporations engaged in lending) are the main resident holders of government debt in all euro area countries except Finland, where a significant proportion of government debt is held by other residents. The domestic central banks generally hold only very limited volumes of government debt in the euro area, with the exception of Cyprus and Malta, where the central banks hold roughly $14 \%$ and $6 \%$ of government debt respectively, and to some degree also in Italy, Spain and Greece, where the central banks hold roughly $3 \%$ to $4 \%$ of existing government debt. Individual resident investors in government bonds play an important role in particular in Malta, Spain, Finland and Germany, and also to some degree in Italy, Portugal and Cyprus.

The government debt of euro area governments is denominated mostly in euro, as shown in Table 14. However, limited amounts of government debt denominated in other currencies were recorded in the Netherlands (around $8 \%$ of government debt is denominated in non-euro currencies) and Austria (less than $3 \%$ of total government debt), Greece, Portugal and Germany (where $1 \%$ to $2 \%$ of total debt is in other currencies), as well as very small amounts 


\section{Table 14 Currency denomination of government debt, 2010}

(percentage of total government debt)

$$
\text { Euro or participating }
$$$$
\text { currencies }
$$

Other currency

\section{Belgium}

Germany

Estonia

Ireland

Greece

Spain

France

Italy

Cyprus

Luxembourg

Malta

Netherlands ${ }^{1)}$

Austria ${ }^{1)}$

Portugal

Slovenia

Slovakia

Finland

Euro area

Source: ESCB.

Notes: Data refer to EDP debt. Gross general government debt at nominal value and consolidated between sub-sectors of government Intergovernmental lending in the context of the financial crisis is consolidated.

1) Data refer to 2009. in Cyprus, Slovakia, Italy, Slovenia and France (less than $0.3 \%$ of total government debt).

Table 15 provides information about the residual maturity of government debt. The highest proportion is typically represented by debt with maturity at over five years. For example, by the end of 2010 Estonia, Slovenia and Austria held more than $50 \%$ of their government debt in instruments with residual maturity at over five years, while for Greece, Italy, Cyprus, Slovakia, Spain, Portugal, Malta, Finland and Belgium the share of instruments with residual maturity at over five years was between 40 and 50\%. Residual maturity at up to one year was particularly high in France, Germany and the Netherlands, in addition to Portugal which is subject to EU/IMF support. A high share of debt maturing in the short term and/or a high share of debt with a variable interest rate will sensitise countries to nominal interest rate developments. The need to maintain price stability is thus crucial for

\section{Table I5 Residual maturity of government debt, 2010}

(percentage of total government debt)

\begin{tabular}{|c|c|c|c|c|c|}
\hline & \multicolumn{5}{|c|}{ Residual maturity } \\
\hline & \multirow[t]{2}{*}{ Up to 1 year } & \multicolumn{2}{|c|}{ Over 1 and up to 5 years } & \multicolumn{2}{|c|}{ Over 5 years } \\
\hline & & & $\begin{array}{l}\text { o/w variable } \\
\text { interest rate }\end{array}$ & & $\begin{array}{l}0 / w \text { variable } \\
\text { interest rate }\end{array}$ \\
\hline Belgium & 24.0 & 35.5 & 0.0 & 40.5 & 0.0 \\
\hline Germany & 28.1 & 35.5 & - & 36.5 & - \\
\hline Estonia & 8.3 & 32.9 & 0.0 & 58.8 & 0.0 \\
\hline Ireland & - & - & - & - & - \\
\hline Greece & 10.2 & 41.5 & 13.8 & 48.3 & 15.3 \\
\hline Spain & 21.5 & 35.9 & 0.0 & 42.6 & 0.0 \\
\hline France & 33.3 & 31.7 & 0.2 & 35.0 & 0.1 \\
\hline Italy & 25.2 & 30.4 & 5.4 & 44.5 & 4.2 \\
\hline Cyprus & 10.6 & 44.9 & 0.0 & 44.5 & 10.2 \\
\hline Luxembourg & 9.0 & - & - & - & - \\
\hline Malta & 13.7 & 45.1 & 1.6 & 41.2 & 0.0 \\
\hline Netherlands ${ }^{1)}$ & 29.6 & 31.7 & 0.0 & 38.7 & 0.0 \\
\hline Austria $^{1)}$ & 8.8 & 34.2 & 0.7 & 57.0 & 0.6 \\
\hline Portugal & 29.5 & 28.5 & 1.3 & 41.9 & 0.2 \\
\hline Slovenia & 8.8 & 34.1 & 3.8 & 57.1 & 0.8 \\
\hline Slovakia & 13.8 & 43.0 & 7.8 & 43.3 & 0.1 \\
\hline Finland & 24.0 & 34.9 & 12.8 & 41.1 & 13.7 \\
\hline Euro area & 26.1 & 33.6 & 2.9 & 40.3 & 2.9 \\
\hline
\end{tabular}

Source: ESCB.

Notes: Data refer to EDP debt. Gross general government debt at nominal value and consolidated between sub-sectors of government. Intergovernmental lending in the context of the financial crisis is consolidated.

1) Data refer to 2009 
maintaining favourable market conditions and allowing governments to refinance at low cost.

Likewise, debt instruments with variable interest rates may also be a preferred option for those investors having to pay variable interest on their liabilities. As shown in Table 15, the higher share of government debt instruments with a variable interest rate is discernible in Greece, Finland and Cyprus, where some $29 \%, 27 \%$ and $10 \%$ of total government debt has a variable interest rate. To illustrate historical developments more clearly, Chart 8 shows 10-year government bond yield spreads vis-à-vis Germany. To some extent the elevated spreads in the past three years for some countries are comparable to those already observed previously, for example in the period between 1994 and 1995. The rapid decline in spreads between 1996 and 1998 is often attributed to the consolidation effort related to the introduction of the single currency. In particular, governments' willingness to comply fully with the Maastricht convergence fiscal criteria was one of the key determinants of government yield convergence and spread decline in that period together with disappearing exchange rate risk premia. It can be expected that a similar determination to that seen in the 1990s will be necessary to bring the currently observed high values of spreads in some of the countries closer to their pre-crisis levels.

The maturity profile (or average residual maturity) and currency denomination is an important factor which affects the refinancing risk. Initial maturity is the lifetime of a financial instrument at issuance, while residual maturity is the time from the reference date until the contractual redemption date of the given instrument. Countries with developed domestic financial markets prefer to issue liabilities in the domestic currency under domestic jurisdiction. The advantage of domestic liabilities denominated in the domestic currency is full control of the conditions under which the debt is repaid. In principle, a country can always service such a debt by increasing existing taxes, imposing new taxes or lowering government discretionary expenditure (each of these three options is
Chart 8 Spreads of 10 -year government bonds vis-à-vis Germany, in basis points

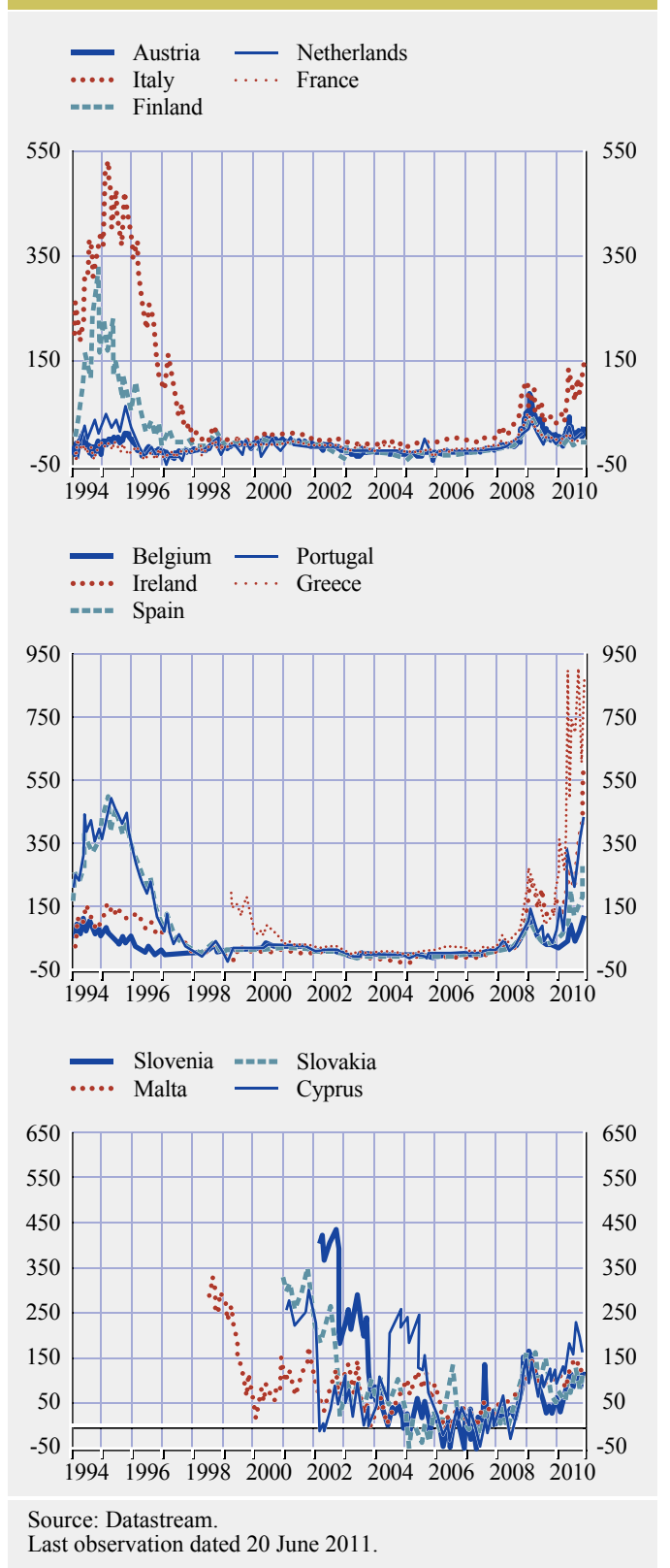

denominated mainly in domestic currency). On the other hand, when government debt is denominated in a foreign currency or under foreign jurisdiction, the government has little or no control over the repayment conditions.

Chart 9 (a) provides a more detailed breakdown of outstanding euro area government debt 
securities and associated changes between December 2007 and December 2010. By end2010 , roughly $22 \%$ of euro area government debt securities were maturing within one year, roughly $37 \%$ will mature at between one to five years, and roughly $41 \%$ of government securities have residual maturity at over five years. As shown in Chart 9 (a) the average residual maturity of euro area government debt securities has been hovering around 6 and 7 years since December 2007 on a slightly declining trend.

Euro area country developments are depicted in Chart 9 (b). Ultimately, as documented by BIS (2011), the financial crisis shifted the environment in which the sovereign debt managers operated: the cut in monetary policy rates generated a steep yield curve. Changes in monetary policy and perceptions of governments' solvency altered the risks and opportunities for debt managers, which led in some cases to the implementation of short-term interest cost minimisation strategies during the crisis. Indeed, the chart shows remarkable changes in the share of short-term government debt. The most visible changes were recorded in Cyprus, Greece and Spain where the share of short-term debt declined between 1995 and 2010 by 54.5 p.p. in Cyprus, 20.4 p.p. in Greece and 13.6 p.p. in Spain, signalling the reduction of rollover risk. In some countries, the share of short-term government debt rapidly declined as a consequence of the improvement in the capital market. On the other hand, opposite developments were recorded in Germany, the Netherlands and Finland where the share of short-term government debt increased respectively by 13.4 p.p., 12.8 p.p. and 6.5 p.p. during the same period.

\section{Chart 9 Residual maturity of government debt securities in the euro area}

a) Outstanding amount of euro area government debt securities and residual maturity

y-axis: percentage GDP (left-hand scale); years (right-hand scale)

$$
\begin{aligned}
& \text { up to } 1 \text { year (left-hand scale) } \\
& \text { over } 5 \text { years (left-hand scale) } \\
& \text { from } 1 \text { to } 5 \text { years (left-hand scale) } \\
& \text { average residual maturity }
\end{aligned}
$$

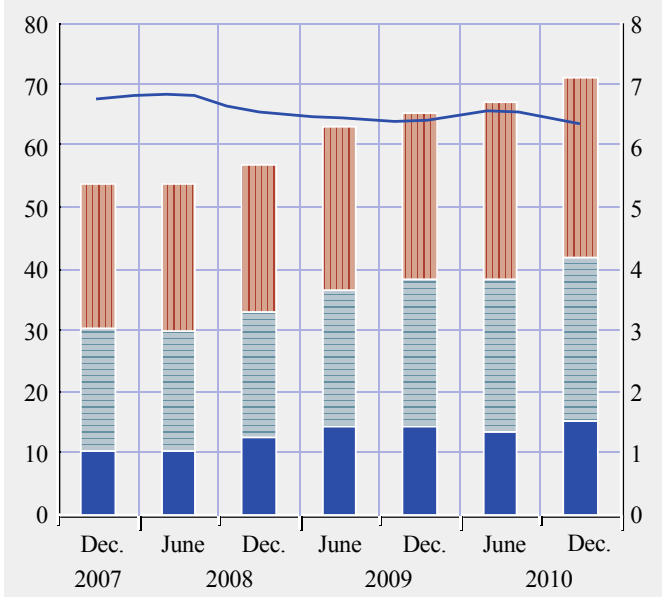

Sources: ECB calculations and ESCB.

Data for Netherlands and Austria refer to 2009 b) Short-term government debt (percentage of GDP, 1995 and 2010)
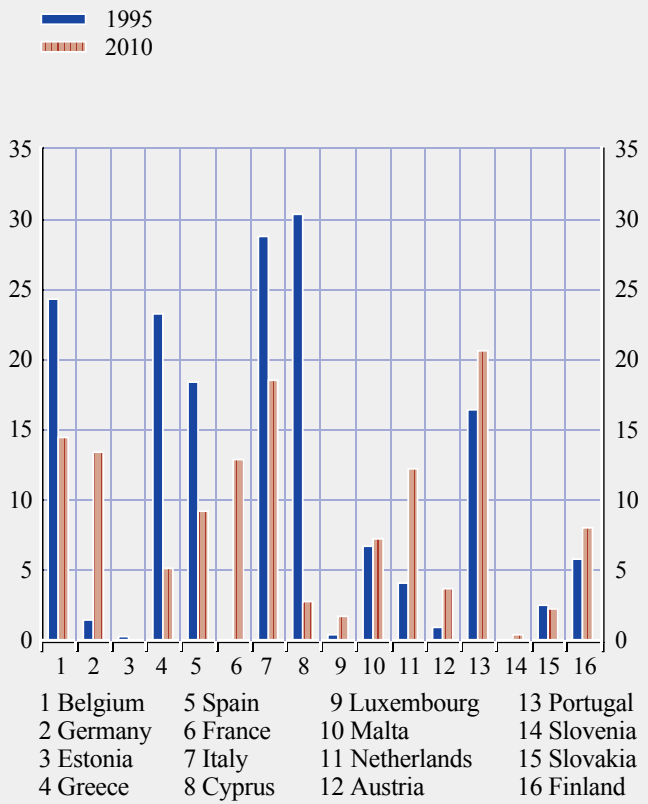
and from the composition of debt reliant on

Sound and sustainable public finances are crucial for the optimal functioning of EMU. The strengthening of EMU's fiscal surveillance framework concentrates, inter alia, on giving greater prominence to government debt and the sustainability of public finances. ${ }^{41}$ Governments in particular need to address the fact that euro area government debt, irrespective of the definition used, has been growing in net and gross terms in the aftermath of the financial and economic crisis and increased by $10 \%$ to $15 \%$ of GDP respectively between 2007 and 2010, an upward trend which is projected to continue. The gross debt concept remains the cornerstone of fiscal surveillance in the EU. At the same time, the financial assets held by governments constitute a buffer that can be used in order to reduce financial market concerns about government solvency.

As well as the debt measurements derived from the government's balance sheet data, there are off-balance-sheet positions, such as the contingent and implicit liabilities (and assets) which must be accounted for in the future and whose adequate estimation, monitoring and analysis are essential. There are contingent liabilities within the euro area originating from government guarantees, which may increase government debt if called, and from the bilateral and multilateral support arrangements for euro area countries in distress. In terms of implicit liabilities, assorted attempts are being made to tackle this rather complex issue which potentially has a high impact on government accounts when the costs of ageing are accounted for. The available long-term estimates are still subject to considerable uncertainty in terms of macroeconomic, demographic and behavioural scenarios. Hence, efforts to improve further the existing estimates of implicit and contingent liabilities (and assets) are of the utmost importance.

Fiscal vulnerabilities are high in the euro area on average and stem from both higher levels of explicit and off-balance-sheet debt

short-term financing and foreign holders. The elevated alertness of investors and their higher risk aversion are accompanied by tighter scrutiny of government accounts and statistics. Market developments have shown that high deficits combined with rapidly growing gross government debt-to-GDP ratios - in some cases far above $60 \%$ of GDP for an extended period of time - need to be avoided in the future. Hence, several euro area governments have had to reduce their existing vulnerabilities and exposure to rollover risks by implementing consolidation strategies, structural reforms and adequate debt management policies. These measures should be aimed, inter alia, at reducing governments' explicit and implicit liabilities and, in the latter instance, at improving the credibility of the long-term sustainability of public finances in the euro area.

Overall, the growing government debt ratios call for an implementation of credible fiscal consolidation strategies to keep government debt on a sustainable path. Lessons need to be drawn and future surveillance analysis should focus more on various government debt indicators. At the same time, analysts need to be aware of various statistical concepts used in government debt measurement, especially the differences between the net and gross concepts and their different implications for government liquidity, solvency and debt sustainability. This also requires better monitoring of governments' implicit and other off-balance-sheet items. As regards the management of government debt and its composition, predictable strategies which are oriented towards limiting refinancing and other risks would contribute to increasing market confidence. 


\section{REFERENCES}

Afonso, A., Checherita, C., Trabandt, M. and Warmedinger, T. (2010), "Euro Area Fiscal Policies: Response to the Economic Crisis", Chapter 3 in van Riet, A. (ed.) (2010), pp. 22-34.

Attinasi, M. G, Checherita, C. and Nickel, C. (2009), "What Explains the Surge in Euro Area Sovereign Spreads during the Financial Crisis of 2007-09?”, ECB Working Paper No 1131.

Attinasi, M.G. (2010), "Euro Area Fiscal Policies: Response to the Financial Crisis", Chapter 2 in van Riet, A. (ed.) (2010), pp. 12-21.

Auerbach, A.J. (2008), "Long-Term Objectives for Government Debt", contribution to the conference on Fiscal Policy and Labour Market Reforms organised by the Swedish Fiscal Policy Council, Stockholm, 29 January.

Balassone, F., Franco, D. and Zotteri, S. (2004), "Public Debt: A Survey of Policy Issues”, Sixth Banca d'Italia Workshop on Public Finance.

Bayoumi, T., Goldstein, M. and Woglom, G. (1995), "Do Credit Markets Discipline Sovereign Borrowers? Evidence from US States", Journal of Money, Credit and Banking, Vol. 27, No 4, Part 1 (Nov.), pp. 1046-1059.

BIS (2011), "Interactions of sovereign debt management with monetary conditions and financial stability", The Committee on the Global Financial System (CGFS) Paper No 42.

Blanchet, D. and Le Minez, S. (2008), "Assessing implicit pension liabilities for the French pension system: a micro-founded approach", paper prepared for the 30th General Conference of the International Association for Research in Income and Wealth (IARIW), August.

Braakmann, A., Grütz, J. and Haug, T. (2007), "Das Renten- und Pensionsvermögen in den Volkswirtschaftlichen Gesamtrechnungen", Statistisches Bundesamt, Wirtschaft und Statistik 12, pp. 1167-1179.

Brixi, H. P. and Schick, A. (ed.) (2002), “Government at Risk - Contingent Liabilities and Fiscal Risk", Oxford University Press.

Bos. F. (2007), “Tijdreeksen overheidsfinancien”, CPB Document 150, Centraal Planbureau.

Buiter, W. H. (1983), "Measurement of the Public Sector Deficit and Its Implications for Policy Evaluation and Design”, IMF Staff Paper, Vol. 30, No 2, June, pp. 306-349.

Buiter, W.H., Persson, T. and Minford, P. (1985), “A Guide to Public Sector Debt and Deficits", Economic Policy, Vol. 1, No 1 (Nov.), pp. 14-79.

Checherita, C. and Rother, P. (2010), "The impact of high and growing government debt on economic growth: an empirical investigation for the euro area", ECB Working Paper No 1237. 
Davig, T. and Leeper, E. M. (2010), "Temporarily Unstable Government and Inflation", IMF Annual Research Conference, 4-5 November.

De Nederlandsche Bank (2010), Statistical Bulletin, March.

Deutsche Bundesbank (2010), "Government debt and interest payment burden in Germany", Monthly Report, April, pp. 15-33.

ECB (2010), "Entitlements of Households under Government Pension Schemes in the Euro Area Results on the Basis of the New System of National Accounts", Monthly Bulletin, January, pp. 85-101.

ECB (2007), "From government deficit to debt: bridging the gap", Monthly Bulletin, April, pp. 87-93.

ECB (2010a), “Government Finance Statistics Guide”, March.

ECB (2010b), "Financial Stability Review”, December.

ECB (2011a), "The reform of economic governance in the euro area - essential elements", Monthly Bulletin, March, pp. 99-119.

ECB (2011b), "Ensuring fiscal sustainability in the euro area", Monthly Bulletin, April, pp. 61-77.

ECB (2011c), “The European Stability Mechanism”, Monthly Bulletin, July, pp. 71-84.

European Commission (2009), “Sustainability Report - 2009”, 9/2009.

European Commission and Economic Policy Committee (2009), "Ageing Report 2009", European Economy No 2.

European Commission (2011), "European Economic Forecast - Spring 2011”, Commission staff working document, $1 / 2011$.

Everaert, G., Fouad, M., Martin, E. and Velloso, R. (2009), "Disclosing Fiscal Risks in the Post-Crisis World", IMF Staff Position Note, No 09/18.

Francese, M., and A Pace, (2008), "Italian public debt since national unification. A reconstruction of the time series", Banca d'Italia, Occasional Paper, No 31, October.

Garcia, J.A. and van Rixtel, A. (2007), "Inflation-linked Bonds from a Central Bank Perspective". ECB Occasional Paper, No 62, June.

Giammarioli, N., Nickel, C., Rother, P. and Vidal, J-P. (2007), "Assessing Fiscal Soundness: Theory and Practice", ECB Occasional Paper, No 56, March.

Holzmann, R. Palacios, P. and Zviniene, A. (2001), "On the economics and scope of implicit pension debt: an international perspective”, Empirica, 28, pp. 97-129. 
IMF (2009a), Handbook on Securities Statistics.

IMF (2009b), "Crisis-Related Measures in the Financial System and Sovereign Balance Sheet Risks", Fiscal Affairs and Monetary and Capital Markets Departments, July.

Lis, E. M., and Nickel, C. (2010), "The Impact of Extreme Weather Events on Budget Balances", International Tax and Public Finance, Vol. 17, pp. 378-399.

Milesi-Ferretti, G. and Moriyama, K. (2004), "Fiscal Adjustment in EU Countries: A Balance Sheet Approach", IMF Working Paper, No 143.

Mink, R., and Rodríguez, M. (2004), "The Measurement of Government Debt in the Economic and Monetary Union", Sixth Banca d'Italia Workshop on Public Finance.

Mink, R., Rodríguez, M., Barredo, E. and Verrinder, J. (2008), "Reflecting Pensions in National Accounts Work of the Eurostat/ECB Task Force", IARIW Conference, Slovenia.

Reinhart, C. M., and Rogoff, K. S. (2008), "The Forgotten History of Domestic Debt", NBER Working Paper, No 13946, April.

Reinhart, C. M., and Rogoff, K. S. (2009), "This Time is Different. Chartbook: Country Histories on Debt, Default, and Financial Crises", NBER Working Paper, No15815.

Rother, P., Schuknecht, L. and Stark, J. (2010), "The Benefits of Fiscal Consolidation in Uncharted Waters", ECB Occasional Paper, No 121, November.

Schuknecht, L., von Hagen, J. and G. Wolswijk (2010), "Government Bond Risk Premium in the EU Revisited: the Impact of the Financial Crisis“, ECB Working Paper, No 1152, February.

Trabandt, M. and Uhlig, H. (2010), "How far are we from the slippery slope? The Laffer curve revisited", ECB Working Paper, No 1174, April.

Van Riet, A. (ed.) (2010), "Euro area fiscal policies and the crisis", ECB Occasional Paper, No 109, April.

Velculescu, D. (2010), "Some Uncomfortable Arithmetic Regarding Europe's Public Finances", IMF Working Paper, No WP/10/177, July.

Wolswijk, G. and de Haan, J. (2005), "Government Debt Management in the Euro Area: Recent Theoretical Developments and Changes in Practices", ECB Occasional Paper, No 25, March.

World Bank (2007), "Managing Public Debt: From Diagnostics to Reform Implementation", World Bank Publishing, ISBN-10: 0-8213-6873-7 (electronic). 


\section{ANNEXES}

I GOVERNMENT EDP DEBT IN EURO AREA COUNTRIES OVER THE PERIOD I999 TO 2012

\section{Government EDP debt in euro area countries over the period 1999 to 2012}

(percentage of GDP)

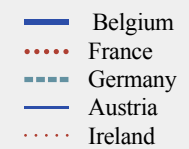

-...-- Portugal

-.- Greece

- - Euro area

-... Spain

-..-- Italy

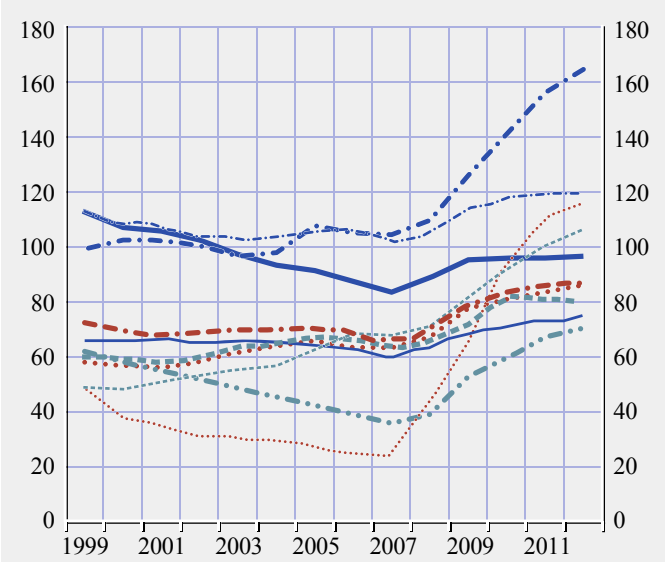

Estonia

-.... Slovenia

=m- Cyprus

- Slovakia

Luxembourg

Finland

-.- Netherlands

-.. Malta

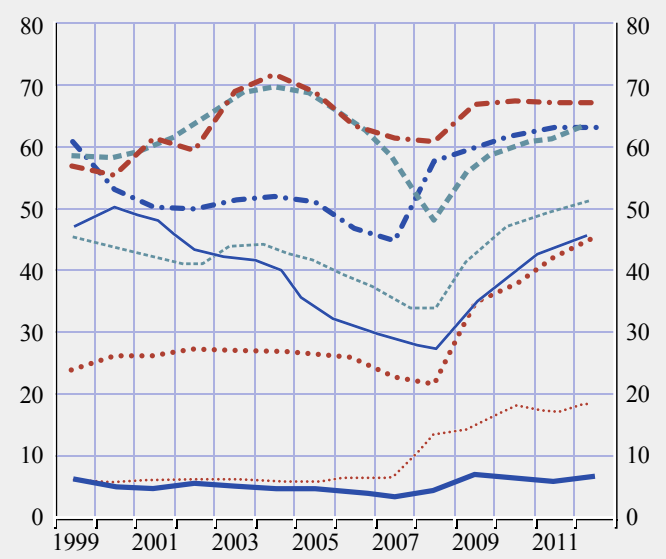

Sources: ECB calculations (based on Eurostat and national data) and European Commission Spring 2011 forecasts (EDP debt for 2011-12) 


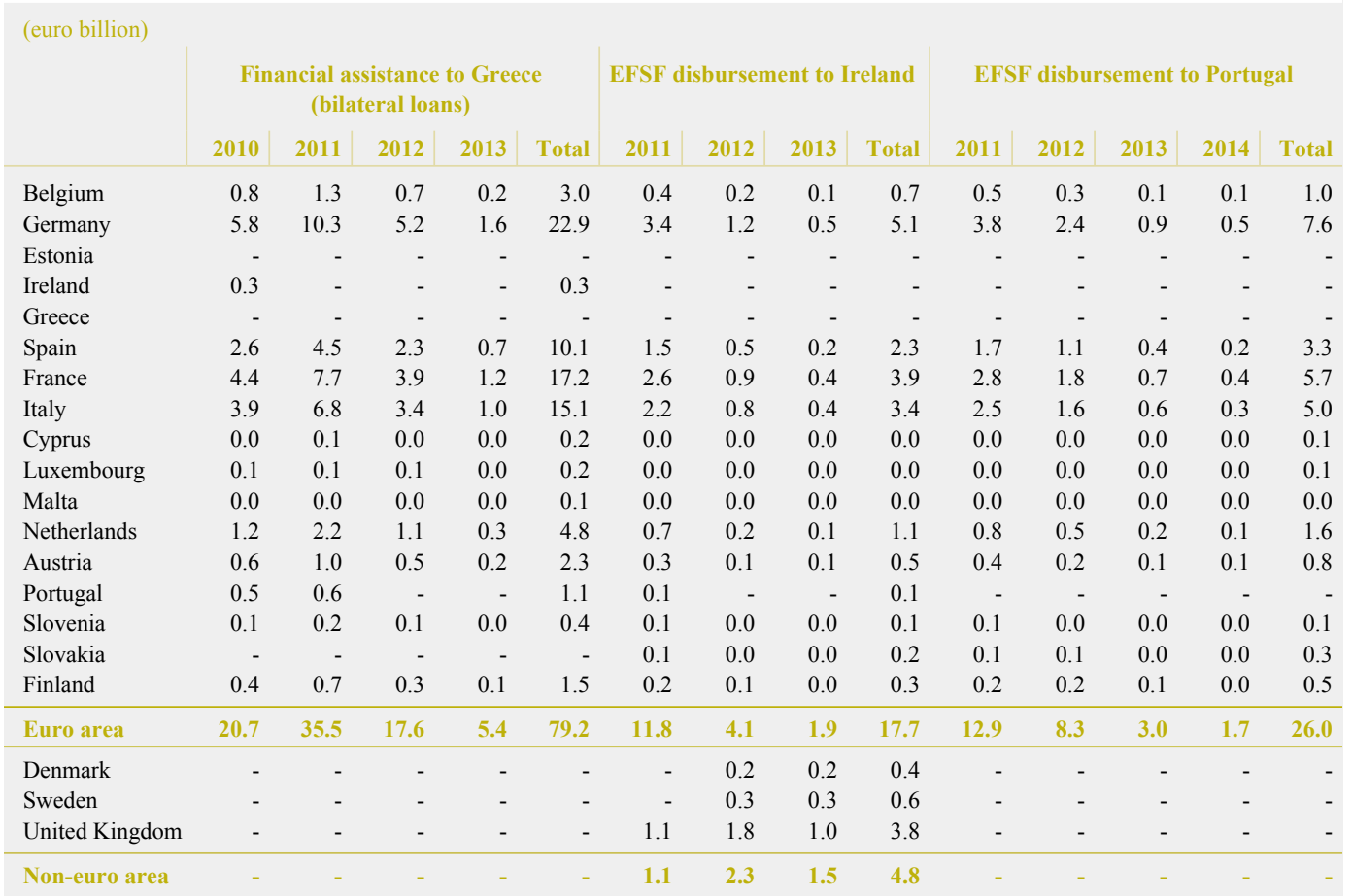

Sources: ESCB. The cut-off date was May 2011. The financial assistance to Greece only includes the bilateral loans provided by the euro

area countries.
Notes: EFSF assistance is assumed to be a constant share of the total assistance provided to Ireland and Portugal over the period 2011-13. 


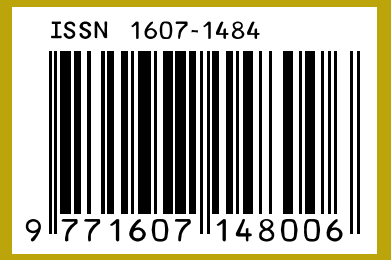

